\title{
External Sector Responses to Oil Price Shocks: A Structural System Model for Nigeria
}

\author{
Chukwuemeka Onyimadu \\ Department of Research and Training, National Institute for Legislative Studies, National Assembly Abuja, Nigeria \\ Email: onyimadu.chukwuemeka@nils.gov.ng
}

How to cite this paper: Onyimadu, C. (2019) External Sector Responses to Oil Price Shocks: A Structural System Model for Nigeria. Theoretical Economics Letters, 9, 2885-2913.

https://doi.org/10.4236/tel.2019.98180

Received: September 18, 2019

Accepted: December 8, 2019

Published: December 11, 2019

Copyright $\odot 2019$ by author(s) and Scientific Research Publishing Inc. This work is licensed under the Creative Commons Attribution International License (CC BY 4.0).

http://creativecommons.org/licenses/by/4.0/

(c) (i) Open Access

\begin{abstract}
This study critically examines the effects of specific exogenous shocks-oil price shocks on Nigeria's external sector. Employing a Structural Macroeconomic Model (SMM) comprising of ten behavioural equations and four identities with quarterly data spanning from 1981 to 2015, the SMM simulations of the external sector found that oil price shocks do have significant impacts on the components of Nigeria's external sector. Specifically, while oil price shocks elicited varying responses from all components of Nigeria's external sector components, the simulated results showed very limited evidence of asymmetry in the responses to both positive and negative oil price shocks. For policy, the simulated responses of capital financial flows, foreign debt flows, imports, nominal exchange rates, reserves, remittances, and capital financial flows, reflect the over-dependence of the Nigerian economy on crude oil, and the justifiable need to diversify the Nigerian economy away from the oil sector.
\end{abstract}

\section{Keywords}

Exogenous Shocks, Diversification, Macroeconomic Modeling, Economic Simulation, Uncertainty

\section{Introduction}

Achieving macroeconomic objectives-economic growth, full employment, price stability and balance of payments stability-remain an integral commitment of the Nigerian government and policy-makers alike. The external sector which is a subset of the general macro economy, as captured by the overall balance of payments account, provides a fundamental connection between Nigeria's dealings with the rest of the world and how actions-trade, capital flows and foreign policy—can influence Nigeria's external sector outcomes. Indeed, to fully 
grasp the workings of Nigeria's macroeconomic structure requires a detailed and thorough study of its external sector and the external sector's role as a possible propagative channel through which exogenous shocks originating outside the economy can affect the domestic real economy. For example, developing open economies like Nigeria depend on trade, consumption of imported goods and foreign direct investments, which have direct consequences on the real, fiscal and financial sectors of its macro economy [1].

The literature on the effects of, especially, oil price shocks (demand side shocks) on the domestic economy for both developing and developed economies is vast [2] and [3]. There is ample evidence to suggest that oil price shocks do matter, as its accompanied windfall revenues may be beneficial or detrimental [4] [5]. To this end, different studies have looked into the role of oil price shocks and the uncertainty caused by oil price shocks on possible responses of selected macroeconomic variables; the effects on economic growth [6], monetary and fiscal policy responses [7] [8] and financial markets [9] [10].

The major problem that now exercises researchers, is not to determine if oil price shocks do matter, as that has been established from the literature. What is of utmost importance is to understand the process by which the effects of these shocks are transmitted to the domestic economy. Empirically this can be achieved by first tracing the effects of these shocks on all components of the shock transmission channel, and secondly, by eliciting the responses of domestic macroeconomic variables from the shock responses of the components of the transmission channel. The channel through which the effects of these exogenous shocks are propagated to the domestic economy is by external sector components. Addressing this problem is important because, as [11] and [12] argued, all shocks are uniquely different in characteristics and transmission. Their argument was based on their findings that the transmission of oil price shocks and the responses to these shocks, depends on if the shock is a positive or negative shock, a large shock or small shock, politically motivated shock or a shock caused by nature, a demand or supply shock. Thus, a proper investigation into any form of exogenous shock will entail a critical study of its transmission channel, i.e. providing an in-depth understanding of the path through which the shock affects the real economy.

The literature on the effects of oil price shocks on the domestic economy for both developing and developed economies has been firmly established [6] [11], [12] [13]. Often, the focus of majority of these studies is directed at the repercussions of these exogenous shocks on output growth, financial deepening, stock market activity, monetary and fiscal policy response, policy uncertainty, inflation and interest rates. However, the transmission channels, i.e. all the components of the external sector through which the propagative effects of these shocks impact the real domestic economy, have been narrow, even though economic theory suggests otherwise [1]. At best, some studies have examined the role, some of the components of Nigeria's external sector; especially exchange 
rates [14], trade [15] and interest rate [16], and foreign investments [17], as possible transmission channels through which exogenous shocks are propagated to Nigeria's real economy. Despite these limited efforts, the literature is scanty on the roles of other important external sector components, like remittances, service exports, foreign portfolio investments and external debt.

This study will provide insights into the responses of Nigeria's external sector, which is an important transmission channel for oil price shocks. Especially in recent times, where global oil price shocks and exchange rate fluctuations are primary concerns for Nigeria, this study will provide detailed understanding on how oil price shocks affect Nigeria's external sector and also provide policy tools for intervention. This will be beneficial to the Nigerian government, policy makers, and all economic agents that partake in the global market place. On this basis, the study sets out to 1) expand on the literature on the effects of oil price shocks. 2) Show the effects of oil price shocks on the Nigerian external sector. 3) Provide policy responses to oil price shocks as it relates to components of Nigeria's external sector and 4) show the existing inter-relationships between components of Nigeria's external sector. In Section 2, the study focuses on the literature review. In Sections 3 and 4, this study provides the methodology used and the results from the simulated model respectively. In Section 5, the paper presents the discussions and findings, and concludes in Section 6.

\section{Literature Review}

From economic literature, the empirical variations in both methods and variables used in macroeconomic modeling of the external sector depend on the peculiarities of the economy being modeled. Macroeconomic models of the external sector therefore reflect the structure and dynamics of individual economies. However, it has become conventional to include the major external sector variables-current account variables, capital account variables in such models as well as variables-such as, exchange rates, interest rates, capital mobility that acts as linkages to both the external sector and the real domestic economy.

The advantages of employing a macro econometric model of an economy or a sub sector cannot be over emphasized. In [18], literature on the methodological issues associated with macroeconomic modeling for a simple household and the macro economy as a whole was provided. In their book "The Econometrics of Macroeconomic Modeling", they emphasized the role of economic theory in macro econometrics and adapting macro econometrics to developments in the real economy and academic research. [18] Noted that over the past twenty years, macro econometric modeling has taken advantage of advances in time series analysis. This has enabled the process of macro econometric modeling to experience less of spurious regressions due to new inferential adaptation of integrated variables, often use of equations that abstract from real world dynamism, and extensive testing of specifications being performed.

In determining the exogenous shocks relevant for this study, the literature on 
modelling external sector components, however few, has provided possible exogenous shocks that may influence the economy of an oil dependent country like Nigeria, [1] elicited the response of the external sector to exogenous shocks to oil prices and oil production quotas, [17] investigated the feedback effects of oil price shocks and oil productivity quota shocks on both the real and external sector. Despite the paucity of studies that focused on Nigeria's external sector, other studies also investigated the effects of exogenous shocks to the external sector; [19] employed oil price, oil productivity quota shocks and foreign economy productivity shocks for India; [20] used the same exogenous shocks as used in [19] but included a foreign interest rate shock for Rwanda. In this study, both negative and positive exogenous shocks will be used to elicit the response of external sector components to shocks in oil price and oil production, foreign countries policy on interest and productivity shocks to major trade countries.

In [21] the external sector was modelled by the balance of payment equilibrium, BoP, where the overall balance of payment equilibrium is the sum of trade balance, $B$ and the balance in capital account, $K$.

$$
B P t=B t+K t
$$

The foreign exchange curve used in the model relates domestic aggregate demand, $Y$, with the level of interest rate, $r$, that exists for a given exchange rate, $\eta$, and aggregate foreign demand, $Y^{f}$. Therefore the persisting foreign exchange, $e$, can be represented as;

$$
r=\alpha_{0}+\alpha_{1} Y+\alpha_{2} Y^{f}+\alpha_{3} e^{r}
$$

Import demand was modeled as a function of income, lags of imports, price of imported goods and services in foreign currency terms, and the real effective exchange rates. Exports on the other hand were modeled as a function of real GDP, lags of export and the prices of exports in terms of the US dollar. [21] Simulated the macro economy of Bangladesh using base line forecast got from estimation of key macroeconomic variables. The study found that devaluing the local currency, raises the real exchange rate in Bangladesh. This causes an increase in aggregate demand and an interest rate differential that encourages capital inflow.

Given the structure of the Nigerian economy as an oil importing as well as an oil exporting country, it becomes paramount to understand the relationship between oil prices and Nigeria's economic growth process as shocks to oil prices are likely to have both direct and indirect effects at the micro and macro levels of the Nigerian economy [22]. Oil price shock literature is divided on the exact and expected effects of these shocks on the economy. Some studies are of the conclusion that oil shocks have detrimental effects on economic performance, inflation, exchange rates and monetary variables [23] [24] [25]. Others are countering this postulate, instead insisting that oil price shocks may have very limited effects on economic activity [22] [26] [27] [28].

Also, the transmission channel through which oil price shocks will affect an economy will depend largely on the economy's sectoral composition, institu- 
tional structures and level of economic development [22]. Studies that concentrated on developing economies show that oil price shocks have remained relevant in determining the extent of macroeconomic activities in such economies [29]. In this study, they found that oil price shocks significantly affected output and exchange rates. Thus, a positive oil price shock will generate exchange rate appreciations which in turn can boost export earnings and drive domestic economic activities. [5] On the other hand, showed that sustained positive oil price shocks can lead to a decline in domestic economic activities for developing countries who are resource rich. Using the "Dutch Disease Syndrome", consistent increases in oil prices for countries that are not well diversified, will bring about oil windfalls that induce the government to concentrate more on the sector of the economy that generates these windfalls. As a result factor inputs and resources are directed to the windfall sector-which is the export sector-at the detriment of other trade sectors of the economy. This will, in the long run, lead to the de-industrialisation of the economy.

From existing literature, considerable amount of studies have focused on understanding the relationship between oil price shocks and aggregate economic performance for various countries [24] [27] [30] [31] [32] [33]. The literature on the effects of oil price shocks can be classified into three broad areas. First, studies that focused more on the transmission mechanism and channels through which oil price effects are propagated on economic activity [34]. Secondly, studies that focused on the nature of the relationship between oil price and aggregate economic activity: Either linear of nonlinear and symmetric or asymmetric [27] [35] [36]. Lastly, studies that focused on proactive macroeconomic policies for dealing with oil price shocks [32] [37].

The full effects of oil price shocks-both positive and negative-on general economic activity will depend to a large extent to what oil producers (government) do with the windfall revenue. [8] has argued that oil price shocks, through fiscal policies, affect economic performance.

[38] Carried out tests on the three leading descriptions of asymmetric and nonlinear response arising from the real price of oil to U.S. industrial production and other sector components. Their results show that estimated responses are sensitive to the estimation period and provide significant support for a nonlinear model especially prior to 1973 . However, with post-1973 data only, the evidence against symmetry becomes considerably weaker. For example, at aggregate levels, the study failed to reject the hypothesis of symmetric responses to oil shocks, which is consistent with results by [39] for U.S. real GDP. Also, at the disaggregate level, there is strong evidence of asymmetries, especially for industries that are energy intensive in production.

For industrialised economies, it was established that shocks to oil prices have detrimental effects on the manufacturing and industrial sectors [40]. However, for these industrialised economies, these detrimental effects diminish easily due to the high quality of their institutions and flexibility of policy structure, allowing for immediate necessary adjustments to these shocks [41]. In the US, [11] 
investigated the oil price shock of 2007-2008 and its effects on the US economy. Though oil price shocks in the US is largely driven by supply side shocks, oil price shocks of 2007-2008 were driven by strong demand. The effects of these demand driven oil price shocks were found to be similar to those of supply driven shocks. Principally, the shocks affected the purchase of domestic automobiles and consumption spending which made a significant contribution to the US recession. [23] showed that increases in the price of oil has a negative impact on economic growth in Japan and China but a positive impact on Russia's economic growth.

[39] Investigated how much real gross domestic product (GDP) respond to unanticipated changes in the real price of oil. Using censored oil price vector autoregressive models, conventional studies suggest a substantial decline in real GDP in response to unexpected increases in the real price of oil, yet no response to unexpected declines. In this study, the authors showed that these estimates are invalid using structural models that include both symmetric and asymmetric considerations. [7] Focused on how monetary authorities should react to an oil price shock. The New Keynesian literature has concluded that ensuring complete price stability is the optimal thing to do. In contrast, the paper argues that a meaningful trade-off between stabilizing inflation and the welfare relevant output gap arises in a distorted economy once one recognizes 1) that oil (energy) cannot be easily substituted by other factors in the short-run, 2) that there is no fiscal transfer available to policymakers to neutralize the steady-state distortion due to monopolistic competition, and 3) that increases in oil prices also directly affect consumption by raising the price of fuel, heating oil, and other energy sources. While the first two conditions are necessary to introduce a micro founded monetary policy trade-off, the third one makes it quantitatively significant. The optimal pre-commitment monetary policy relies on unobservables and is therefore hard to implement. To address this concern, the study derives a simple interest rate feedback rule that mimics the optimal plan in all relevant dimensions but that depends only on observables, namely core inflation, oil price inflation, and the growth rate of output (see [42]).

\section{Methodology}

The external sector model to be constructed will consist of eleven behavioral equations and three identities. The behavioral equations will include oil export, non-oil export, total imports, reserves, exchange rate, foreign direct investment, foreign debt flow, foreign portfolio investment, remittances, and services, which are the components of the external sector to be estimated. The study employed SMM appropriate econometric technique based on the characteristics of the data for the period 1980-2015. The system modelling used in this study will estimate a group of equations containing unknown parameters (parameters attributed to exogenous variables). SMM allows for the examination of simulated results under assumptions that are peculiar to exogenous variables. Thus, various multivariate techniques can be used in estimating the unknown parameters as well as 
consider the interdependence that exists between the equations in the system. The general form of the system model is:

$$
f_{i}=\left(y_{t}, y_{t-1}, y_{t-p}, x_{t}, \alpha_{i}\right)=\mu_{i t}, \quad i=1, \cdots, n ; t=1, \cdots, T
$$

where $y_{t}$ represents a vector of endogenous variables, $x_{t}$ is a vector of exogenous variables and $\alpha_{i}$ is a vector of parameters to be estimated in the system model. $\epsilon_{t}$ is a vector of possible serially correlated disturbance terms in the system model and $f$ is a vector of real-valued functions. Endogenous variables are determined within the model while exogenous variables are determined outside the model. All equations in the model have a unique endogenous variable attached to it such that, each equation in the model can be represented as:

$$
Y_{i}=f\left(y_{i}, x_{i}, \alpha_{i}\right)
$$

where $y_{i}$ is the endogenous variable in equation $i$. Any variable that is not assigned as an endogenous variable becomes an exogenous variable. The equations in the system model are divided into stochastic and identities. Identities are equations that are expected to hold in reality while stochastic equations are those that can only hold with a random error ${ }^{1}$. Stochastic equations will be gotten from the estimation of the equations in the system model, while identities are derived from accounting relationships amongst variables.

The behavioral equations in the SMM will be estimated using ordinary least square (OLS) with the inclusions of lags for both dependent and independent variables in each behavioral equation. [43] Describes the possible use of OLS in estimating an SMM. According to [43], macroeconomic models are normally nonlinear, simultaneous and very large, thus they tend to have serially correlated error terms. However, the features of the SMM allows for the correction of these problems in modeling the SMM. From equation 3.2, the SMM provides a convenient way of correcting for the problem of serial correlation by treating the serial correlation coefficients as structural coefficients and transforms the equations into equations with serially uncorrelated error terms $[43]^{2}$.

Thus, the SMM used in estimating the effects of exogenous shocks on Nigeria's external sector components is adapted and improved upon from [1] and comprises the following behavioral equations written in their mathematical form:

$$
\begin{aligned}
& X_{0}=f\left(P_{0}, O P E C, Y^{f}\right), \quad X_{n}=f\left(N E R, Y^{f}, Y_{n}\right), X_{s}=f(Y, X, R E R), \\
& M=f\left(Y^{d}, R E R, M L R, R E S\right), R E S=f\left(R E R, P_{0}, E D S, X_{0}\right), \\
& N E R=f\left(R E S, R M T, I R D, X / M, C P I, T G E, P_{0}\right), F D I=f\left(F D I_{t-k}, P C G D P, X_{n}\right), \\
& F P I=f\left(Y, Y^{f}, S M R, I N T^{f}, N E R\right), F D F=f\left(I R D, N E R, C R, M, Y^{f}\right),
\end{aligned}
$$

*Stochastic equations express the endogenous variables, identities are relationships that are expected to hold in real life and do not have any stochastic characteristics.

${ }^{2}$ Assume $\mu_{i t}=\rho_{i} \mu_{i t-1}+\epsilon_{i t} \quad(t=2, \cdots, T)$ where $\epsilon_{i t}$ does not have serial correlated properties. Taking lags of this equation and subtracting it from the original equation 3.2, we get

$f\left(y_{i}, x_{i}, \alpha_{i}\right)-\rho f\left(y_{i-1}, x_{i-1}, \alpha_{i}\right)=\mu_{i t}-\rho_{i} \mu_{i t-1}=\epsilon_{i t}$. This transformation removes the problem of serial correlation when using OLS to estimate the behavioural equations in an SMM. 
$R M T=f\left(N E R, Y^{u s}\right)$

On the basis of these mathematical equations, the econometric behavioral equations to be estimated will be in the form of a double log equation:

Behavioral equations

$$
\begin{aligned}
& L O G X_{0}=V_{0,1}+V_{1,1} L O G P_{0(t-2)}+V_{2,1} L_{O G O P E C} C_{(t-2)}+V_{3,1} L O G Y_{(t-1)}^{f} \\
& +V_{4,1} L O G X_{0(t-3)}+\mu_{1} \\
& L O G X_{n}=V_{0,2}+V_{1,2} R E R+V_{2,2} L O G Y_{(t-2)}^{f}+V_{3,2} L O G Y_{n(t-2)} \\
& +V_{4,2} L O G X_{n(t-3)}+\mu_{2} \\
& L O G X_{s}=V_{0,3}+V_{1,3} L O G Y+V_{2,3} L O G X_{(t-2)}+V_{3,3} R E R+V_{4,3} L O G X_{s(t-3)}+\mu_{3} \\
& L O G M=V_{0,4}+V_{1,4} L O G Y_{(t-2)}^{d}+V_{2,4} R E R+V_{3,4} M L R_{(t-1)}+V_{4,4} L O G R E S_{(t-3)} \\
& +V_{5,4} L O G M_{(t-2)}+\mu_{4} \\
& \text { LOGRES }=V_{0,5}+V_{1,5} R E R+V_{2,5} P_{0}+V_{3,5} \text { EDS }_{t-1}+V_{4,5} \operatorname{LOGM}_{(t-2)} \\
& +V_{5,5} \text { LOGRES }_{(t-3)}+V_{6,5} L O G Y_{(t-2)}+\mu_{5} \\
& N E R=V_{0,6}+V_{1,6} L O G R E S+V_{2,6} \operatorname{LOGRMT}_{(t-1)}+V_{3,6} I_{R D_{(t-1)}}+V_{4,6} \frac{X}{M} \\
& +V_{5,6} C P I_{(t-1)}+V_{6,6} \operatorname{LOGTGE}_{(t-1)}+V_{7,6} P_{0(t-2)}+V_{8,6} N E R_{(t-3)}+\mu_{6} \\
& \text { LOGFDI }=V_{0,7}+V_{1,7} L_{\text {OOGCGDP }}+V_{(t-2)}+V_{2,7} L O G X_{n(t-4)} \\
& +V_{3,7} \operatorname{LOGFDI}_{(t-2)}+\mu_{7} \\
& F P I=V_{0,8}+V_{1,8} Y_{(t-1)}+V_{2,8} Y_{(t-2)}^{f}+V_{3,8} S M R+V_{4,8} I N T_{(t-2)}^{f} \\
& +V_{5,8} N E R_{(t-2)}+V_{6,8} F_{(t-3)}+\mu_{8} \\
& \text { LOGFDF }=V_{0,9}+V_{1,9} I_{R D_{(t-1)}}+V_{2,9} N E R_{(t-2)}+V_{3,9} C R_{(t-2)}+V_{4,9} L_{O G M} M_{(t-4)} \\
& +V_{5,9} L O G Y_{(t-2)}^{f}+V_{6,9} L_{O O G F D F}(t-4)+\mu_{9} \\
& \text { LOGRMT }=V_{0,10}+V_{1,10} N E R+V_{2,10} L O G Y^{u s}+V_{3,10} L_{O G R M T} T_{(t-3)}+\mu_{10}
\end{aligned}
$$

Identities

$$
\begin{gathered}
R E R=N E R *(F C P I / C P I) \\
X=X_{0}+X_{n} \\
C A=X-M-I N V I-X s+C T \\
C F=F D I+F P I+O I
\end{gathered}
$$

where $X_{0}$ is oil exports, $P_{0}$ is oil prices, OPEC represents OPEC quota and $Y^{u s}$ represents output from the United States of America, $X_{n}$ is non-oil exports, $N E R$ is the nominal exchange rates, $Y_{n}$ is non-oil GDP, $X_{s}$ is service exports, $X$ is the value of exports, and $R E R$ is the real exchange rate, $M$ is imports, $Y^{d}$ represents personal disposable income, $M L R$ is domestic lending rate, RES is external reserves, $E D S$ is external debt services, $F D I$ represents foreign direct investment, $P C G D P$ is per capita income, RES is foreign reserves, $R M T$ is remittances, IRD is the interest rate differential, $X / M$ is the terms of trade, $C P I$ is the consumer price index, $F C P I$ is foreign country CPI (we used the CPI of the United States 
given that the nominal exchange rate is expressed in dollar terms), $T G E$ is total government expenditure comprising both recurrent and capital expenditure, FPI represents foreign portfolio investment, $Y$ is domestic GDP, $S M R$ is stock market returns proxied by the returns on the All Share Index (ASI), INTf is interest rate for OECD countries, $F D F$ represents foreign debt flow, $Y^{F}$ is the income or foreign output proxy by OECD, $C R$ represents the credit risk of the borrowing country proxied by the ratio of gross debt to GDP, $R M T$ represents remittances, $I N V I$ represents investment income, $C A$ is the current account balance, $C F$ is capital financial flows, $O I$ represents other investments in the capital account and $C T$ represents the net current transfers as captured in the current account balance.

\section{Results}

The external sector components that are used to make up the SMM in this study comprises of ten behavioural equations-oil export, non-oil exports, service exports, imports, external reserves, foreign debt flow, remittances, foreign direct investments, foreign portfolio investments, and nominal exchange rates-and four identities. The behavioural equations are estimated in the model using OLS, with the amount of lags included for each variable determined by the Akaike information Criterion (AIC). The appropriate optimal lag length chosen for each variable in each behavioural equation, was done in such a way that the estimated errors for each behavioural equation will not exhibit serial correlation properties. The estimates of the behavioural equation provide close estimates of the actual historical data, which will be used in simulating a baseline for the mode.

\subsection{Oil Export Equation}

The estimated behavioural equation for oil exports in Table 1 showed the first lag of oil exports had positive sign while other lags had negative signs. For oil price and foreign income, the estimated signs were negative, unlike for OPEC oil production which showed a positive sign in the first lag and negative for subsequent lags. There are positive feedback innovations for oil exports equation. The estimated indicated that oil prices might not immediately have effects of oil exports, with this same conclusion plausible for OPEC oil production.

\subsection{Non-Oil Export Equation}

The estimates on non-oil export equation in Table 2 showed that previous quarter values of non-oil exports have strong links with the current value of non-oil exports. Also, non-oil output, real exchange rates and foreign country output also suggestively explain the variations in Nigeria's non-oil exports. There are negative feedback innovations for non-oil exports equation.

\subsection{Service Export Equation}

Estimates of the service export equation in Table 3 suggests important 
Table 1. Model estimation result for oil exports.

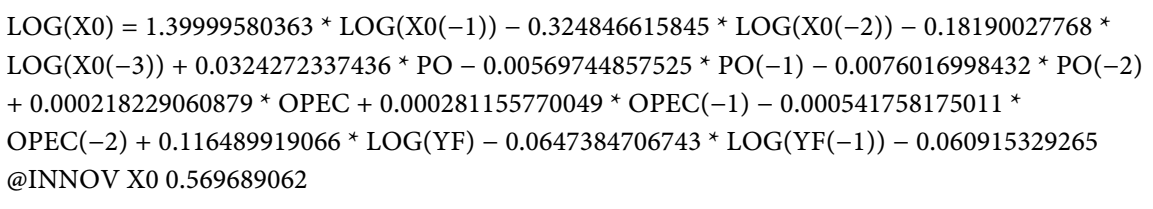

Source: Author's computation from SMM.

Table 2. Model estimation result for non-oil exports.

$\operatorname{LOG}(\mathrm{XN})=1.39999580363$ * $\operatorname{LOG}(\mathrm{XN}(-1))-0.324846615845 * \operatorname{LOG}(\mathrm{XN}(-2))-0.18190027768$ *

$\mathrm{LOG}(\mathrm{XN}(-3))+0.0324272337436$ * RER $-0.00569744857525 *$ LOG(YF) -0.0076016998432 *

$\mathrm{LOG}(\mathrm{YF}(-1))+0.000218229060879 * \mathrm{LOG}(\mathrm{YF}(-2))+0.000281155770049 * \mathrm{LOG}(\mathrm{YN})-$

$0.000541758175011 * \operatorname{LOG}(\mathrm{YN}(-1))+0.116489919066 * \mathrm{LOG}(\mathrm{YN}(-2))-0.0647384706743$ @INNOV XN 0.8183643748

Source: Author's computation from SMM.

Table 3. Model estimation result for service exports.

$\operatorname{LOG}(X S)=1.39999580363 * \operatorname{LOG}(\mathrm{XS}(-1))-0.324846615845 * \operatorname{LOG}(\mathrm{XS}(-2))-0.18190027768$ *

$\mathrm{LOG}(\mathrm{XS}(-3))+0.0324272337436$ * $\mathrm{LOG}(\mathrm{Y})-0.00569744857525 * \mathrm{LOG}(\mathrm{X})-0.0076016998432$ *

$\mathrm{LOG}(\mathrm{X}(-1))+0.000218229060879 * \mathrm{LOG}(\mathrm{X}(-2))+0.000281155770049 * \mathrm{RER}-$

0.000541758175011

@INNOV XS 0.4567353275

Source: Author's computation from SMM.

relationships between lags of service exports and current exports. Also, the estimates for real exchange rate and domestic output were found to have positive signs in explaining the variations in service exports, but total value of lags of exports was found to have a negative response in explaining the variations in service exports. There are negative feedback innovations for service exports equation.

\subsection{Import Equation}

From economic theory, we modelled Nigeria's imports to depend on lags of imports, domestic income, real exchange rates, domestic lending rates and reserves. The estimated equation in Table 4 showed inertia properties for imports, where previous period imports had causal effects on current imports. Also, domestic income suggests possible effects on the variations of imports. However, the results from the estimates of domestic income did not conform to theory, where increases in consumption (via increases in domestic income) will increase the demand for imported commodities. There are positive feedback innovations for the imports equation.

\subsection{Reserves Equation}

According to [1], one of government's core objectives is to preserve the value of the Naira, which is directly linked to the country's reserves. Thus, we modelled Nigeria's reserves to depend on lags of reserves, the real exchange rates, oil 
Table 4. Model estimation result for imports.

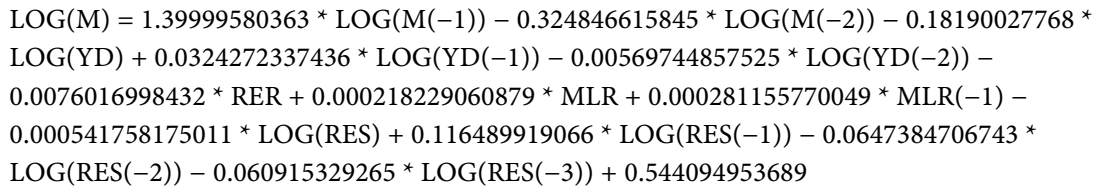

Source: Author's computation from SMM.

prices, external debt servicing, imports and domestic output. From the estimates of the equation in Table 5, there is evidence of negative responses of lags of reserves in explaining current reserve levels. Also, we found that oil prices, imports and domestic output have negative effect on reserves. External debt services were found to have positive feedback in explaining the variations in reserves at all lags. There are positive feedback innovations for reserves equation.

\subsection{Nominal Exchange Rate Equation}

Exchange rate is a key factor in Nigeria's external sector because it reflects changes in both the domestic and foreign country macroeconomic fundamentals. Based on this, we modelled Nigeria's exchange rate with lags of nominal exchange rates [1], reserves, remittances, interest differentials, terms of trade, consumer price index, total government expenditure, and oil prices. Our estimates in Table 6 showed that the first lag of nominal exchange rates has positive effect on current exchange rates. Other variables showed a mixture of positive and negative effects at different levels of lags. Reserves, interest rate differentials, consumer price index and Total government expenditure all had positive effects on the nominal exchange rate. Oil prices and lags of nominal exchange rates on the other hand, have negative effects on current nominal exchange rates. There are negative feedback innovations for nominal exchange rate equation.

\subsection{Foreign Direct Investment Equation}

The sustained rise in FDI and its consequent importance on the Nigerian economy has been traced to economic reforms that allowed for foreign investments in telecommunication, construction and the oil and Gas sectors. Thus, we modelled FDI as a function of per capita GDP, non-oil exports and lags of FDI to capture inertia effects where current FDI flows are affected by previous FDI flows. From the estimated equation in Table 7, we found inertia effects on FDI, while per capita GDP is seen to have both positive and negative effects on FDI at first and second lags respectively. However, the variable for non-oil exports showed a positive effect on FDI at first and fourth lags. FDI. There are negative feedback innovations for foreign direct investments equation.

\subsection{Foreign Portfolio Investment Equation}

Just like the equation of FDI, foreign portfolio investments remain an important component of Nigeria's capital and financial accounts. Due to reforms, especially 
Table 5. Model estimation result for external reserves.

$\operatorname{LOG}($ RES $)=1.39999580363 * \operatorname{LOG}(\operatorname{RES}(-1))-0.324846615845 * \operatorname{LOG}(\operatorname{RES}(-2))-0.18190027768$

${ }^{*} \mathrm{LOG}(\mathrm{RES}(-3))+0.0324272337436 * \mathrm{RER}-0.00569744857525 * \mathrm{PO}-0.0076016998432 *$ EDS + $0.000218229060879 * \operatorname{EDS}(-1)+0.000281155770049 * \mathrm{LOG}(\mathrm{M})-0.000541758175011$ *

$\mathrm{LOG}(\mathrm{M}(-1))+0.116489919066 * \mathrm{LOG}(\mathrm{M}(-2))-0.0647384706743 * \mathrm{LOG}(\mathrm{Y})-0.060915329265$ *

$\mathrm{LOG}(\mathrm{Y}(-1))+0.544094953689$ * $\mathrm{LOG}(\mathrm{Y}(-2))-0.326038734525$

@INNOV RES 2.817776461

Source: Author's computation from SMM.

Table 6. Model estimation result for nominal exchange rates.

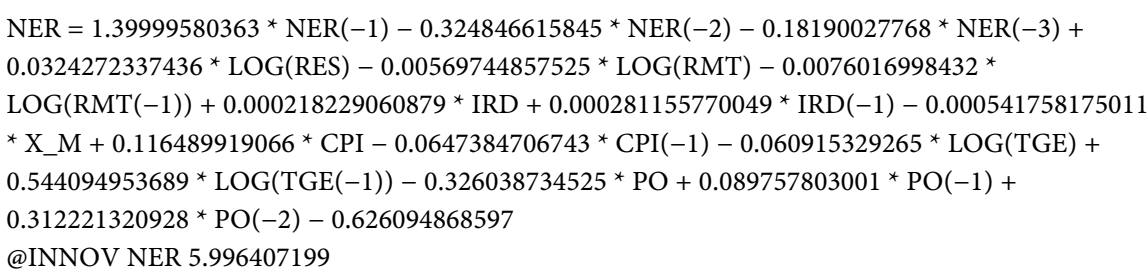

Source: Author's computation from SMM.

Table 7. Model estimation result for foreign direct investments.

$\mathrm{LOG}(\mathrm{FDI})=1.39999580363 * \mathrm{LOG}(\mathrm{FDI}(-1))-0.324846615845 * \mathrm{LOG}(\mathrm{FDI}(-2))-0.18190027768$

${ }^{*} \mathrm{LOG}(\mathrm{PCGDP})+0.0324272337436 *$ LOG $(\mathrm{PCGDP}(-1))-0.00569744857525 * \operatorname{LOG}(\operatorname{PCGDP}(-2))$

-0.0076016998432 * $\mathrm{LOG}(\mathrm{XN})+0.000218229060879 * \mathrm{LOG}(\mathrm{XN}(-1))+0.000281155770049$ *

$\mathrm{LOG}(\mathrm{XN}(-2))-0.000541758175011 * \mathrm{LOG}(\mathrm{XN}(-3))+0.116489919066{ }^{\star} \mathrm{LOG}(\mathrm{XN}(-4))-$

0.0647384706743

@INNOV FDI 1.695581558

Source: Author's computation from SMM.

those reforms targeted at equity participation, there has been increasing flows of portfolio investment to the Nigerian Economy [1]. Thus, we modelled FPI as a function of domestic output, foreign country output, stock market returns, foreign country interest rates, and nominal exchange rates. From the estimates in Table 8, both domestic and foreign country output have a strong significant effect in explaining the variations in FPI. While the effect for domestic output on FPI is negative, the effect of foreign output is positive in the first two lags but becomes negative by the third lag. The stock market returns variable is negative, while foreign interest rates and nominal exchange rates show positive effects in explaining the variations in FPI. There are positive feedback innovations in the foreign portfolio investments equation.

\subsection{Foreign Debt Equation}

The equation for foreign debt is based on theoretical explanations on the expected determinants of FDF [1]. On this basis, we modelled foreign debt flow as a function of the amount of imports, interest rate differentials, nominal exchange rates, country risk, foreign country output, and lags of foreign debt flows. The estimated equation in Table 9 showed a strong influence of the level of 
Table 8. Model estimation result for foreign portfolio investments.

LOGFPI $=1.39999580363 *$ LOGFPI $(-1)-0.324846615845 *$ LOGFPI $(-2)-0.18190027768$ * LOGFPI $(-3)+0.0324272337436 *$ LOG $(\mathrm{Y})-0.00569744857525 * \operatorname{LOG}(\mathrm{Y}(-1))-0.0076016998432$ ${ }^{*} \mathrm{LOG}(\mathrm{YF})+0.000218229060879 * \mathrm{LOG}(\mathrm{YF}(-1))+0.000281155770049 * \mathrm{LOG}(\mathrm{YF}(-2))-$ $0.000541758175011 * \mathrm{SMR}+0.116489919066$ * INTF $-0.0647384706743 * \operatorname{INTF}(-1)-$ $0.060915329265 * \operatorname{INTF}(-2)+0.544094953689 * \mathrm{NER}-0.326038734525 * \mathrm{NER}(-1)+$ $0.089757803001 * \mathrm{NER}(-2)+0.312221320928$ @INNOV FPI 116.0960255

Source: Author's computation From SMM.

Table 9. Model estimation result for foreign debt flow.

LOGFDF $=1.39999580363{ }^{\star} \operatorname{LOGFDF}(-1)-0.324846615845^{*} \operatorname{LOGFDF}(-2)-0.18190027768$ * LOGFDF $(-3)+0.0324272337436 * \operatorname{LOGFDF}(-4)-0.00569744857525 * \operatorname{LOG}(\mathrm{M})-$ $0.0076016998432 * \mathrm{LOG}(\mathrm{M}(-1))+0.000218229060879 * \mathrm{LOG}(\mathrm{M}(-2))+0.000281155770049$ * $\mathrm{LOG}(\mathrm{M}(-3))-0.000541758175011$ * $\mathrm{LOG}(\mathrm{M}(-4))+0.116489919066$ * IRD -0.0647384706743 * $\mathrm{IRD}(-1)-0.060915329265 * \mathrm{NER}+0.544094953689 * \mathrm{NER}(-1)-0.326038734525 * \mathrm{NER}(-2)+$ $0.089757803001 * \mathrm{CR}+0.312221320928 * \mathrm{CR}(-1)-0.626094868597$ * $\mathrm{CR}(-2)+11.4807096219$ * LOG(YF) -27.5395211629 * LOG $(\mathrm{YF}(-1))+14.4583810946$ * LOG $(\mathrm{YF}(-2))+35.8257864344$ @INNOV FDF 85.73134111

Source: Author's computation From SMM.

imports, nominal exchange rates, foreign country output and country risk. However, it is difficult to interpret the direction of the effects due to the changes in causal effects at different lags. Despite this drawback, the estimated results clearly show that imports, nominal exchange rates, foreign country output and lags of FDF demonstrate strong influences over the variations of FDF. There are positive feedback innovations in the foreign debt flow equation.

\subsection{Remittances Equation}

Remittances have become very important to the Nigerian Economy, given that it has become a viable source of foreign exchange and revenue for the government. Thus, we modelled remittances as a function of United States of America's output, nominal exchange rates and lags of remittances. From Table 10, we found strong positive effects in the first lag of remittances and negative effects in subsequent lags, while the nominal exchange rate showed negative effects in explaining changes in remittances. Output from the United States of America was estimated to have positive effects on remittances. There are negative feedback innovations for remittances equation.

\subsection{Simulation Results for Within-Sample SMM}

Using the estimated behavioural equations, we introduce all the variables-endogenous and exogenous-and identities into the SMM and solve the SMM block using the Gauss-Seidel method. The first step in using the Gauss-Seidel method to study the effects of exogenous shocks on the external sector components is to compare actual and simulated within-sample values for all the endogenous variables. This comparison will provide an assessment of the 
Table 10. Model estimation result for remittances.

$\mathrm{LOG}(\mathrm{RMT})=1.39999580363$ * $\mathrm{LOG}(\mathrm{RMT}(-1))-0.324846615845 * \mathrm{LOG}(\mathrm{RMT}(-2))-$

$0.18190027768 *$ LOG $($ RMT $(-3))+0.0324272337436 *$ LOG(YUS $)-0.00569744857525 *$ NER 0.0076016998432

@INNOV RMT 1.071626221

Source: Author's computation From SMM.

SMM against the historical data on all endogenous variables and serve as a baseline for future simulations. To achieve this, the Gauss-Seidel method uses actual values for both exogenous and lagged endogenous variables in the SMM. This is necessary because it is the within-sample simulation of the external sector components that provides a test for the reliability of the SMM given that historical data already exist for these external sector components.

To initialise the SMM for estimating within samples, we simulate the data adjusting the dataset to allow for the inclusion of lagged variables. Since the data ranges from 1981Q1-2015Q4, we simulate for the baseline starting from 1982Q1-2015Q1. The simulation results of the SMM showed that the simulated results for the components of Nigeria's external sector perform well (See Figure 1). This is viewed from the simulated result's ability to track the historical data as well as to follow the general trend and characteristics of the historical data. However, the SMM includes more fluctuations in predicting foreign debt flows and foreign portfolio investments. Despite this, the simulated results performed quite well in predicting the general trend for these two variables, making them appropriate for simulating the SMM.

\subsection{Out-of-Sample Simulation Results with Exogenous Shocks}

With satisfactory within-sample simulations for the SMM (See Figure 1), we provide out-of-sample simulations for the external sector components, assuming the exogenous variables experience some form of shock. With this assumption, the SMM will be able to track changes in all the external sector components. First, we have to provide a benchmark forecast of the external sector components, which will then form the yardstick for comparing simulated responses to shocks of the external sector components. Also, we introduce different scenarios to capture our assumptions of changes to the exogenous shock variables, while also assuming that the conditions within the benchmark will hold true in the future. For the different scenarios, we will track the responses of the external sector components to positive and negative changes to the exogenous shock variables-oil price, OPEC production, foreign interest rates, and foreign productivity. For the benchmark forecast of the external sector components, we assume that all components follow their trend-assume no change occurs in all variables.

\subsection{Scenarios Simulation Criteria}

To simulate the effects of oil price shocks on the external sector components, we 


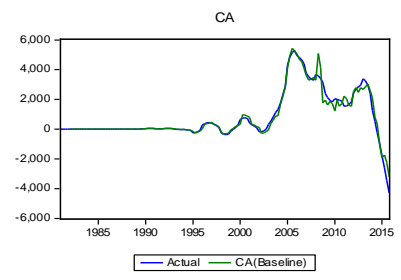

FPI

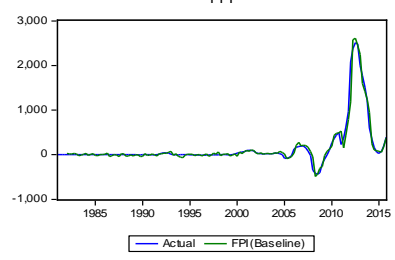

RES
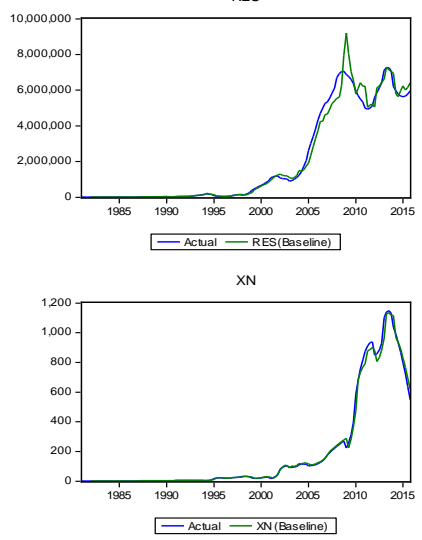

CF
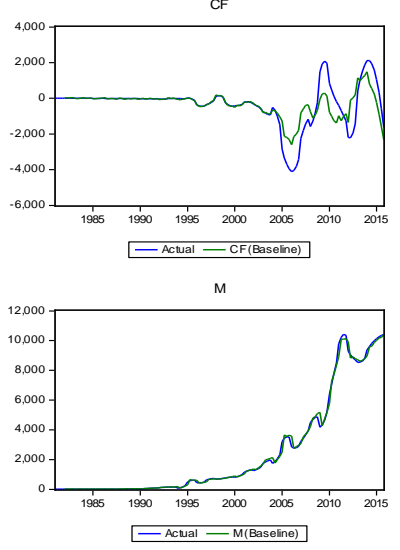

RMT
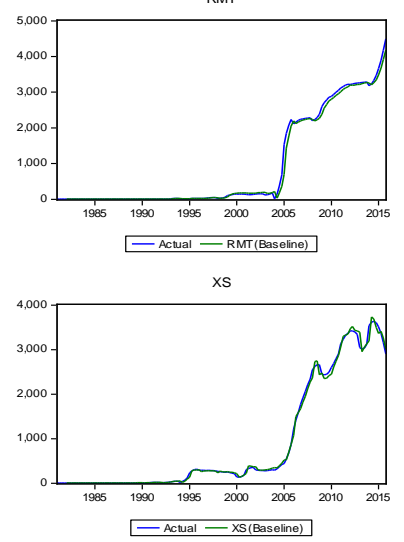

FDF

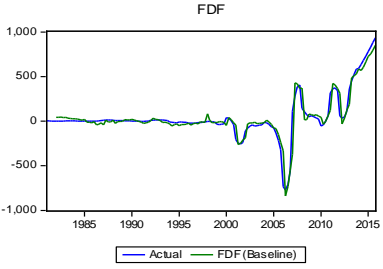

NER
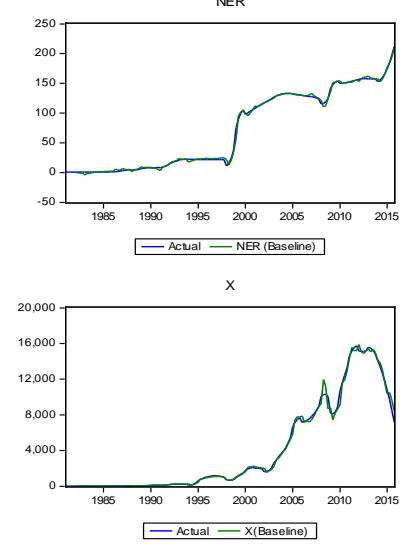

FDI

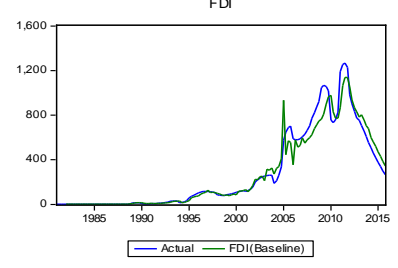

RER
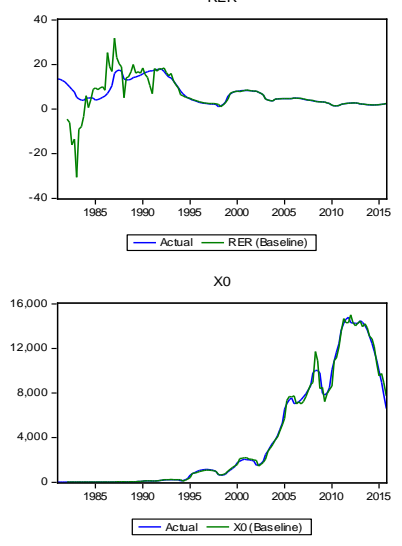

Figure 1. Actual and simulated values for endogenous variables. Source: Author's computation. The reported simulations are in the following order: CA, CF, FDF, FDI, FPI, M, NER, RER, RES, RMT, X, X0, XN, XS. All responses in this study will be ordered in this format.

assume the following scenarios to simulate both positive and negative shocks of the exogenous variables within the period 2016Q1 to 2017Q4:

Benchmark Forecast:

1) Scenario 1: All variables in the model continue on their trend path, i.e. assume no changes in all variables.

Exogenous shocks

2) Scenario 2: We assume that oil prices will increase to 100 dollars per barrel (pre-2015) prices and remain at that level.

3) Scenario 3: We assume that oil prices will reduce to 35 dollars per barrel and remain at that level.

To effectively simulate these exogenous shock scenarios in the SMM, we will have to provide a benchmark forecast for the forecast and simulation range (2016Q1-2017Q4) and also for other exogenous variables in the SMM that do not comprise our shock variables (See Table 11). This is necessary as the historical data for these variables ends at 2015Q4. Without providing values for 2016Q1-2017Q4 for these variables, the Gauss-Seidel method will not be able to provide accurate simulations for the endogenous variables. We solved this problem by assuming $s$ that all the exogenous variables will continue along their trend, i.e. no significant shifts in their trend and cycles and they continue in 
Table 11. Benchmark forecast for external sector components.

\begin{tabular}{|c|c|c|c|c|c|c|c|c|}
\hline \multirow[b]{2}{*}{ Variable } & \multicolumn{4}{|c|}{2016} & \multicolumn{4}{|c|}{2017} \\
\hline & Q1 & Q2 & Q3 & Q4 & Q1 & Q2 & Q3 & Q4 \\
\hline CA ( billion) & -3727.90 & -2641.70 & -1297.40 & 123.8 & 1485.20 & 2686.40 & 3659.10 & 4369.80 \\
\hline $\mathrm{CF}(\mathrm{billion})$ & -2732.70 & -2735.80 & -2507.50 & -2143.60 & -1720.40 & -1301.70 & -931.7 & -636.7 \\
\hline FDF ( billion) & 908.9 & 856.3 & 797.6 & 753.6 & 732.8 & 737.1 & 764 & 808.9 \\
\hline FDI ( billion) & 299.1 & 323.4 & 350.4 & 374.3 & 398.6 & 422.9 & 447.6 & 472.4 \\
\hline FPI ( billion) & 589.7 & 793.4 & 979 & 1135.80 & 1257.30 & 1341.50 & 1390.20 & 1407.70 \\
\hline M ( billion) & $10,363.50$ & $10,306.00$ & $10,305.00$ & $10,386.10$ & $10,556.80$ & $10,812.00$ & $11,142.20$ & $11,536.10$ \\
\hline NER & 227.5 & 242.5 & 257.4 & 272.1 & 286.8 & 301.5 & 316 & 330.4 \\
\hline RER & 2.6 & 2.7 & 2.7 & 2.6 & 2.5 & 2.4 & 2.3 & 2.1 \\
\hline RES ( billion) & $6.45 \mathrm{E}+06$ & $6.90 \mathrm{E}+06$ & $7.39 \mathrm{E}+06$ & $7.82 \mathrm{E}+06$ & $8.22 \mathrm{E}+06$ & $8.55 \mathrm{E}+06$ & $8.83 \mathrm{E}+06$ & $9.06 \mathrm{E}+06$ \\
\hline RMT ( billion) & 1,318 & 484.07 & 203.16 & 90.223 & 42.601 & 21.318 & 11.238 & 6.2114 \\
\hline $\mathrm{X}$ ( billion) & 7411.08 & 8202.28 & 9401.36 & $10,835.70$ & $12,381.30$ & $13,927.00$ & $15,389.00$ & $16,713.90$ \\
\hline X0 ( billion) & 6868.07 & 7637.47 & 8792.11 & $10,168.40$ & $11,648.10$ & $13,125.10$ & $14,519.50$ & $15,780.90$ \\
\hline XN ( billion) & 543 & 564.8 & 609.2 & 667.2 & 733.1 & 801.9 & 869.5 & 933 \\
\hline XS ( billion) & 2796.90 & 2663.90 & 2583.10 & 2551.70 & 2583.80 & 2680.30 & 2839.10 & 3054.40 \\
\hline
\end{tabular}

Source: Author's computation. Forecast period from 2016Q1 to 2017Q4 assuming a no change in the trend of the endogenous variables. For reference, we call this Scenario 1. Deviations from this assumed path will detail the response to external sector components to exogenous shocks.

their projected paths for the periods 2016Q1-2017Q4. We first provide simulations for our benchmark for the external sector components for the period 2016Q1 to 2017Q4, on the assumption of no significant shifts in the trend of all the external sector components.

\subsection{Oil price Shock Simulation Results}

We present the SMM simulations for positive oil price shocks and then the results for negative oil price shocks. In simulating the effects of oil price shocks, we assumed that the price of oil will increase to its pre-2015 levels at 100 dollars per barrel and all the other exogenous variables will continue on their trend path and not deviate from it within the time of the simulated results.

The output of the simulation in Table 12 showed that a positive oil price shock brought about significant decreases in capital financial flows, foreign debt flow, foreign portfolio investments, imports, nominal exchange rates, real exchange rates and reserves. However, positive oil price shocks caused substantial increases in total exports, oil exports, non-oil exports, and service exports. It must be stated clearly that the responses of non-oil exports and remittances are very small relative to other responses from other external sector components. A closer look at the simulation results and the percentage deviations show with an increase in oil prices to $\$ 100$, the following responses of external sector components were elicited; 
Table 12. Response of External sector components to a positive oil price shock.

\begin{tabular}{|c|c|c|c|c|c|c|c|c|c|}
\hline \multicolumn{6}{|c|}{2016} & \multicolumn{4}{|c|}{2017} \\
\hline & Q1 & Q2 & Q3 & Q4 & & Q1 & Q2 & Q3 & Q4 \\
\hline \multicolumn{10}{|c|}{$\mathrm{CA}$} \\
\hline Scenario 2 ( billion) & -2345.21 & 960.6684 & 4177.91 & 7192.58 & Scenario 2 (billion) & 9750.89 & $11,771.90$ & $13,258.00$ & $14,272.70$ \\
\hline Scenario 1 ( billion) & -3727.90 & -2641.70 & -1297.40 & 123.8 & Scenario 1 ( billion) & 1485.20 & 2686.40 & 3659.10 & 4369.80 \\
\hline Deviation ( billion) & 1382.60 & 3602.40 & 5475.30 & 7068.80 & Deviation ( billion) & 8265.70 & 9085.50 & 9598.90 & 9902.90 \\
\hline \% Deviation & -37.1 & -136.4 & -422 & 5711.30 & \% Deviation & 556.5 & 338.2 & 262.3 & 226.6 \\
\hline \multicolumn{10}{|c|}{$\mathrm{CF}$} \\
\hline Scenario 2 ( billion) & -2748.70 & -2792.80 & -2583.60 & $-2,238.20$ & Scenario 2 ( billion) & -1823.60 & -1407.10 & -1033.00 & -729.5 \\
\hline Scenario 1 ( billion) & -2732.70 & -2735.80 & -2507.50 & -2143.60 & Scenario 1 ( billion) & -1720.40 & -1301.70 & -931.7 & -636.7 \\
\hline Deviation ( billion) & -16 & -57 & -76.1 & -94.6 & Deviation ( billion) & -103.1 & -105.4 & -101.3 & -92.8 \\
\hline \% Deviation & 0.6 & 2.1 & 3 & 4.4 & \% Deviation & 6 & 8.1 & 10.9 & 14.6 \\
\hline \multicolumn{10}{|c|}{ FDF } \\
\hline Scenario 2 ( billion) & 893.1 & 804.9 & 732.7 & 670.7 & Scenario 2 ( billion) & 635.4 & 623 & 632.7 & 659.5 \\
\hline Scenario 1 ( billion) & 908.9 & 856.3 & 797.6 & 753.6 & Scenario 1 ( billion) & 732.8 & 737.1 & 764 & 808.9 \\
\hline Deviation ( billion) & -15.8 & -51.4 & -64.9 & -82.9 & Deviation ( billion) & -97.4 & -114.1 & -131.3 & -149.4 \\
\hline \% Deviation & -1.7 & -6 & -8.1 & -11 & \% Deviation & -13.3 & -15.5 & -17.2 & -18.5 \\
\hline \multicolumn{10}{|c|}{ FDI } \\
\hline Scenario 2 ( billion) & 299.1 & 323.5 & 350.8 & 374.9 & Scenario 2 ( billion) & 399.5 & 424.1 & 449.1 & 474.3 \\
\hline Scenario 1 ( billion) & 299.1 & 323.4 & 350.4 & 374.3 & Scenario 1 ( billion) & 398.6 & 422.9 & 447.6 & 472.4 \\
\hline Deviation ( billion) & 0.03 & 0.16 & 0.36 & 0.62 & Deviation ( billion) & 0.92 & 1.23 & 1.54 & 1.84 \\
\hline \% Deviation & 0.01 & 0.05 & 0.1 & 0.17 & \% Deviation & 0.23 & 0.29 & 0.34 & 0.39 \\
\hline \multicolumn{10}{|c|}{ FPI } \\
\hline Scenario 2 ( billion) & 573.7 & 736.3 & 902.5 & 1040.50 & Scenario 2 ( billion) & 1153.20 & 1235.00 & 1287.40 & 1313.00 \\
\hline Scenario 1 ( billion) & 589.7 & 793.4 & 979 & 1135.80 & Scenario 1 ( billion) & 1257.30 & 1341.50 & 1390.20 & 1407.70 \\
\hline Deviation ( billion) & -16 & -57.1 & -76.5 & -95.3 & Deviation ( billion) & -104 & -106.6 & -102.9 & -94.7 \\
\hline \% Deviation & -2.72 & -7.2 & -7.81 & -8.39 & \% Deviation & -8.28 & -7.95 & -7.4 & -6.73 \\
\hline \multicolumn{10}{|c|}{ M } \\
\hline Scenario 2 ( billion) & $10,142.60$ & 9770.82 & 9375.14 & 9018.20 & Scenario 2 ( billion) & 8720.15 & 8486.29 & 8312.27 & 8191.05 \\
\hline Scenario 1 ( billion) & $10,363.50$ & $10,306.00$ & $10,305.00$ & $10,386.10$ & Scenario 1 ( billion) & $10,556.80$ & $10,812.00$ & $11,142.20$ & $11,536.10$ \\
\hline Deviation ( billion) & -220.9 & -535.2 & -929.9 & -1367.90 & Deviation ( billion) & -1836.60 & -2325.70 & -2829.90 & -3345.10 \\
\hline \% Deviation & -2.1 & -5.2 & -9 & -13.2 & \% Deviation & -17.4 & -21.5 & -25.4 & -29 \\
\hline \multicolumn{10}{|c|}{ NER } \\
\hline Scenario $2(\sharp)$ & 224.2 & 230.5 & 241.2 & 252.6 & Scenario $2(\$)$ & 264.9 & 277.7 & 290.7 & 304 \\
\hline Scenario $1(\mathbb{N})$ & 227.5 & 242.5 & 257.4 & 272.1 & Scenario 1 ( $)$ & 286.8 & 301.5 & 316 & 330.4 \\
\hline Deviation & -3.3 & -12 & -16.1 & -19.6 & Deviation & -21.9 & -23.8 & -25.2 & -26.4 \\
\hline$\%$ Deviation & -1.45 & -4.93 & -6.27 & -7.19 & \% Deviation & -7.65 & -7.89 & -7.99 & -8 \\
\hline
\end{tabular}




\section{Continued}

\begin{tabular}{|c|c|c|c|c|c|c|c|c|c|}
\hline \multicolumn{10}{|c|}{ RER } \\
\hline Scenario 2 ( $)$ & 2.5 & 2.5 & 2.5 & 2.4 & Scenario 2 ( $)$ & 2.4 & 2.2 & 2.1 & 1.9 \\
\hline Scenario 1 ( $)$ & 2.6 & 2.7 & 2.7 & 2.6 & Scenario 1 ( & 2.5 & 2.4 & 2.3 & 2.1 \\
\hline Deviation & -0.04 & -0.13 & -0.17 & -0.19 & Deviation & -0.19 & -0.19 & -0.18 & -0.17 \\
\hline \% Deviation & -1.45 & -4.93 & -6.27 & -7.19 & $\%$ Deviation & -7.65 & -7.89 & -7.99 & -8 \\
\hline \multicolumn{10}{|c|}{ RES } \\
\hline Scenario 2 ( billion) & $5.33 \mathrm{E}+06$ & $4.87 \mathrm{E}+06$ & $4.45 \mathrm{E}+06$ & $4.12 \mathrm{E}+06$ & Scenario 2 (billion) & $3.85 \mathrm{E}+06$ & $3.63 \mathrm{E}+06$ & $3.44 \mathrm{E}+06$ & $3.27 \mathrm{E}+06$ \\
\hline Scenario 1 ( billion) & $6.45 \mathrm{E}+06$ & $6.90 \mathrm{E}+06$ & $7.39 \mathrm{E}+06$ & $7.82 \mathrm{E}+06$ & Scenario 1 (billion) & $8.22 \mathrm{E}+06$ & $8.55 \mathrm{E}+06$ & $8.83 \mathrm{E}+06$ & $9.06 \mathrm{E}+06$ \\
\hline Deviation ( billion) & $-1.12 \mathrm{E}+06$ & $-2.03 E+06$ & $-2.94 \mathrm{E}+06$ & $-3.70 \mathrm{E}+06$ & Deviation ( billion) & $-4.37 \mathrm{E}+06$ & $-4.93 \mathrm{E}+06$ & $-5.40 \mathrm{E}+06$ & $-5.79 \mathrm{E}+06$ \\
\hline \% Deviation & -17.4 & -29.5 & -39.8 & -47.3 & $\%$ Deviation & -53.2 & -57.6 & -61.1 & -63.9 \\
\hline \multicolumn{10}{|c|}{ RMT } \\
\hline Scenario 2 ( billion) & 1,322 & 491.4 & 209.11 & 94.302 & Scenario 2 (billion) & 45.243 & 23.007 & 12.321 & 6.9155 \\
\hline Scenario 1 ( billion) & 1,318 & 484.07 & 203.16 & 90.223 & Scenario 1 (billion) & 42.601 & 21.318 & 11.238 & 6.2114 \\
\hline Deviation ( billion) & 4.47 & 7.33 & 5.95 & 4.08 & Deviation ( billion) & 2.64 & 1.69 & 1.08 & 0.7 \\
\hline \% Deviation & 0.3 & 1.5 & 2.9 & 4.5 & \% Deviation & 6.2 & 7.9 & 9.6 & 11.3 \\
\hline \multicolumn{10}{|c|}{$\mathrm{X}$} \\
\hline Scenario 2 ( billion) & 8829.95 & $11,745.70$ & $14,545.10$ & $17,284.10$ & Scenario 2 ( billion) & $19,714.40$ & $21,766.10$ & $23,422.10$ & $24,720.90$ \\
\hline Scenario 1 ( billion) & 7411.08 & 8202.28 & 9401.36 & $10,835.70$ & Scenario 1 (billion) & $12,381.30$ & $13,927.00$ & $15,389.00$ & $16,713.90$ \\
\hline Deviation ( billion) & 1418.90 & 3543.40 & 5143.80 & 6448.40 & Deviation ( billion) & 7333.10 & 7839.10 & 8033.10 & 8007.00 \\
\hline \% Deviation & 19.1 & 43.2 & 54.7 & 59.5 & \% Deviation & 59.2 & 56.3 & 52.2 & 47.9 \\
\hline \multicolumn{10}{|c|}{$\mathrm{X} 0$} \\
\hline Scenario 2 ( billion) & 8286.86 & $11,180.50$ & $13,935.00$ & $16,615.30$ & Scenario 2 ( billion) & $18,978.80$ & $20,960.90$ & $22,548.40$ & $23,782.90$ \\
\hline Scenario 1 ( billion) & 6868.07 & 7637.47 & 8792.11 & $10,168.40$ & Scenario 1 (billion) & $11,648.10$ & $13,125.10$ & $14,519.50$ & $15,780.90$ \\
\hline Deviation ( billion) & 1418.80 & 3543.00 & 5142.90 & 6446.80 & Deviation ( billion) & 7330.70 & 7835.80 & 8028.90 & 8002.00 \\
\hline \% Deviation & 20.7 & 46.4 & 58.5 & 63.4 & \% Deviation & 62.9 & 59.7 & 55.3 & 50.7 \\
\hline \multicolumn{10}{|c|}{$\mathrm{XN}$} \\
\hline Scenario 2 ( billion) & 543.1 & 565.2 & 610.1 & 668.8 & Scenario 2 ( billion) & 735.6 & 805.2 & 873.7 & 938 \\
\hline Scenario 1 ( billion) & 543 & 564.8 & 609.2 & 667.2 & Scenario 1 ( billion) & 733.1 & 801.9 & 869.5 & 933 \\
\hline Deviation ( billion) & 0.08 & 0.38 & 0.89 & 1.6 & Deviation ( billion) & 2.44 & 3.34 & 4.22 & 4.98 \\
\hline \% Deviation & 0.01 & 0.07 & 0.15 & 0.24 & \% Deviation & 0.33 & 0.42 & 0.49 & 0.53 \\
\hline \multicolumn{10}{|c|}{ XS } \\
\hline Scenario 2 ( billion) & 3054.00 & 3140.20 & 3181.50 & 3299.20 & Scenario 2 ( billion) & 3487.90 & 3759.60 & 4103.20 & 4503.60 \\
\hline Scenario 1 ( billion) & 2796.90 & 2663.90 & 2583.10 & 2551.70 & Scenario 1 ( billion) & 2583.80 & 2680.30 & 2839.10 & 3054.40 \\
\hline Deviation ( billion) & 257.1 & 476.2 & 598.4 & 747.5 & Deviation ( billion) & 904.1 & 1079.30 & 1264.10 & 1449.20 \\
\hline \% Deviation & 9.2 & 17.9 & 23.2 & 29.3 & $\%$ Deviation & 35 & 40.3 & 44.5 & 47.4 \\
\hline
\end{tabular}

Source: Author's computation. Scenario 2 represents responses of external sector components to an oil price increase, while Scenario 1 represents the benchmark forecast. Underneath each variable's response is the deviation and percentage deviation of the responses to an oil price increase from the benchmark forecast. 
1) Current account balance continuously increases during the forecast period by $37 \%$ and above $200 \%$ in $2016 \mathrm{Q} 1$ and $2017 \mathrm{Q} 4$ respectively.

2) Capital financial flows increase by $0.6 \%$ to $14.6 \%$ in $2016 \mathrm{Q} 1$ and $2017 \mathrm{Q} 4$ respectively.

3) Foreign debt flow decrease by $1.7 \%$ to $18.5 \%$ in $2016 \mathrm{Q} 1$ and $2017 \mathrm{Q} 4$ respectively.

4) Foreign direct investment increase by $0.01 \%$ to $0.39 \%$ in $2016 \mathrm{Q} 1$ and 2017Q4 respectively.

5) Foreign portfolio investments decrease by $2.72 \%$ to $6.73 \%$ in $2016 \mathrm{Q} 1$ and 2017Q4 respectively.

6) Imports decrease by $2.1 \%$ to $29 \%$ in $2016 \mathrm{Q} 1$ and $2017 \mathrm{Q} 4$ respectively.

7) Nominal exchange rates appreciate from $\$ 1: \mathrm{N} 227$ to $\$ 1: \mathrm{N} 224.2$ by $2016 \mathrm{Q} 1$ and from $\$ 1$ :N330.4 to $\$ 1: \mathrm{N} 304$ by 2017Q4.

8) Real exchange rates also appreciates by $1.45 \%$ to $8 \%$ in $2016 \mathrm{Q} 1$ and $2017 \mathrm{Q} 4$ respectively.

9) Reserves decrease by $17.4 \%$ to $63.9 \%$ in $2016 \mathrm{Q} 1$ and $2017 \mathrm{Q} 4$ respectively.

10) Remittances increase by $0.3 \%$ to $11.3 \%$ in $2016 \mathrm{Q} 1$ and $2017 \mathrm{Q} 4$ respectively.

11) Total exports increase by $19.1 \%$ to $47.9 \%$ in $2016 \mathrm{Q} 1$ and $2017 \mathrm{Q} 4$ respectively. Oil exports also increase by $20.7 \%$ to $50.7 \%$ in $2016 \mathrm{Q} 1$ and $2017 \mathrm{Q} 4$ respectively, while service exports also increase by $9.2 \%$ to $47.4 \%$ in $2016 \mathrm{Q} 1$ and 2017Q4 respectively. However, non-oil exports increased marginally by $0.01 \%$ to $0.53 \%$ in $2016 \mathrm{Q} 1$ and $2017 \mathrm{Q} 4$ respectively.

With the increase in oil prices-as captured by the positive oil price shock, Nigeria gains more in foreign exchange earnings which ultimately significantly increases her reserves and inflow of remittances. With the increases in reserves, Nigeria will be able to cover more of her imports putting less pressure on the Naira and therefore the currency appreciates in value. The simulation results show a reduction in nominal exchange rates showing that positive oil price shocks will lead to the appreciation of the Naira but imports did not increase as expected.

As expected, there was a significant increase in reserves and remittances, which seemed to be a permanent change from the benchmark. Similarly, total exports, service exports and oil exports behaved similarly with respect to their responses. Relative to total exports, service exports and oil exports, non-oil exports responded with just a marginal increase (See Figure 2).

In simulating responses to a negative oil price shock, we assumed the world oil price will drop to 35 dollars per barrel and all the other exogenous variables will continue on their trend path and not deviate from it within the time of the simulated results. The output of the simulation in Table 13 showed that a negative oil price shock brought about significant decreases in current account balance, total exports, oil exports, and service exports. However, negative oil price shocks also brought about increases in capital financial flows, foreign debt flow, foreign portfolio investments, imports, nominal exchange rates, real exchange 

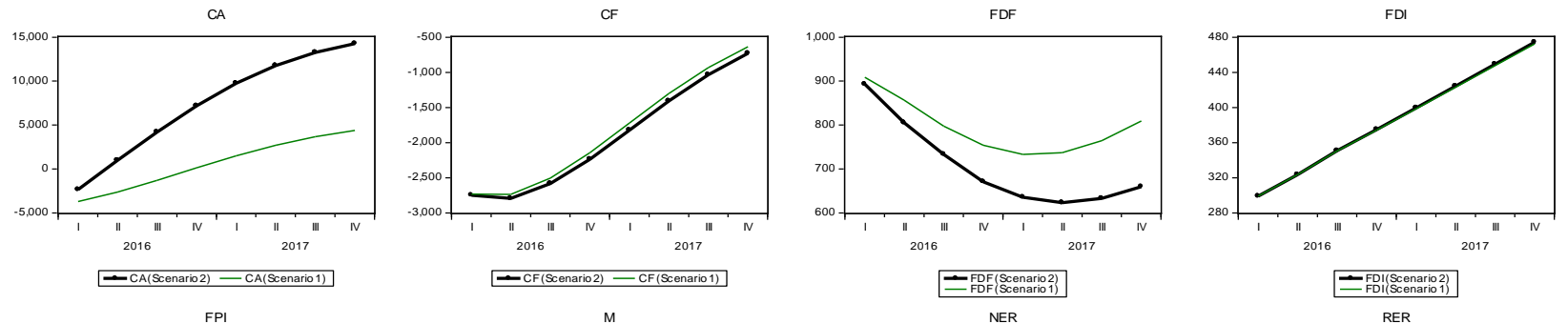

FPI

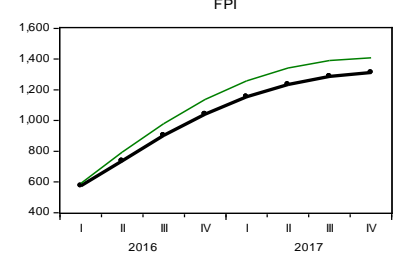

M
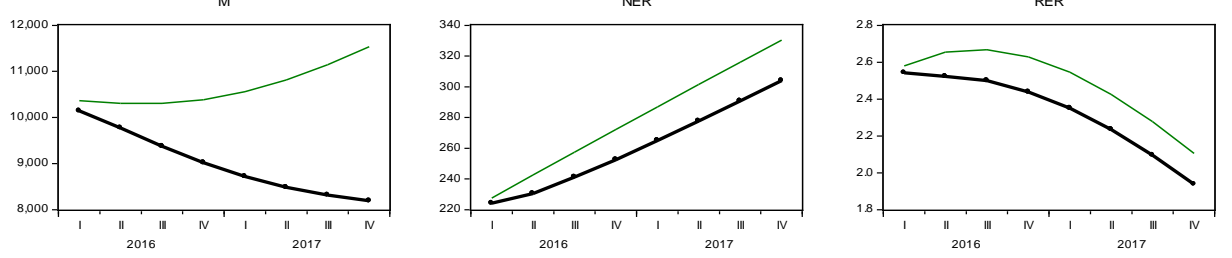

三吕(Scenario 2)

RES

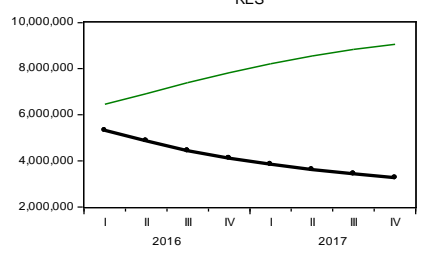

$-M($ Scenario 2) $-M($ Scenario 1)

RMT
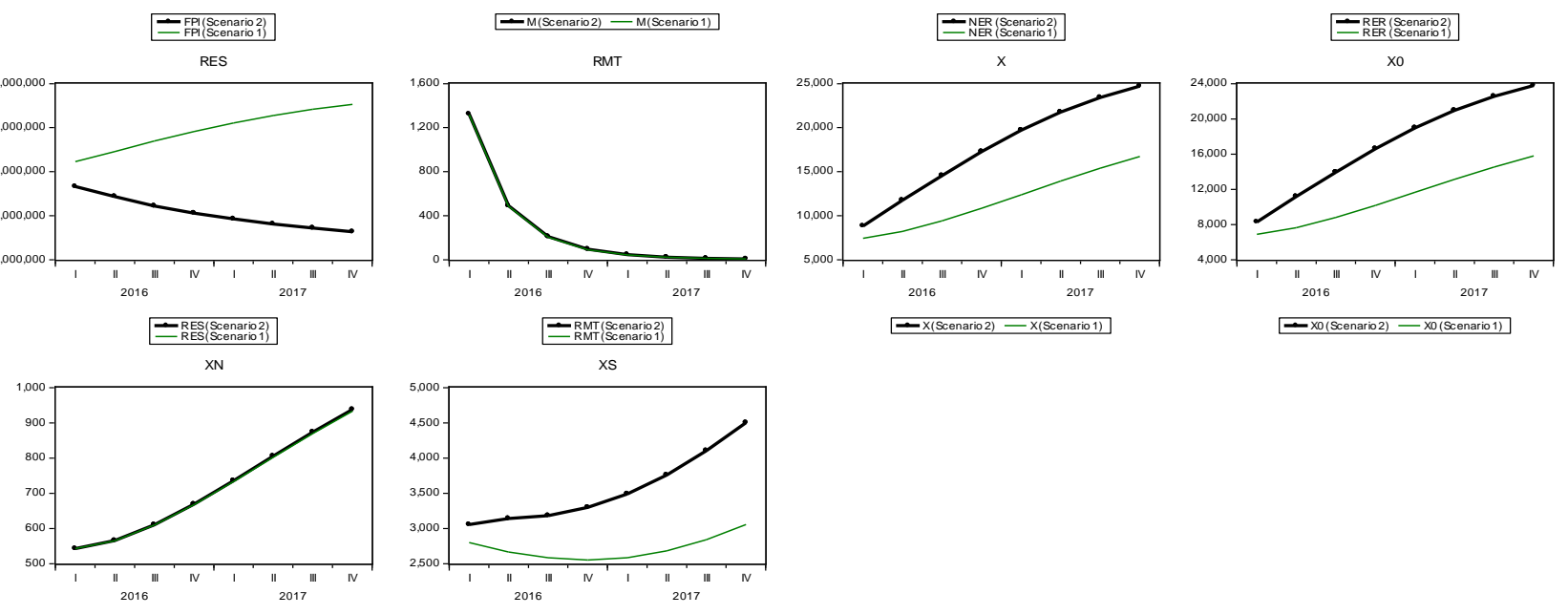

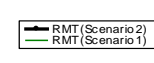

-X(Scenario 2) - X(Scenario 1)
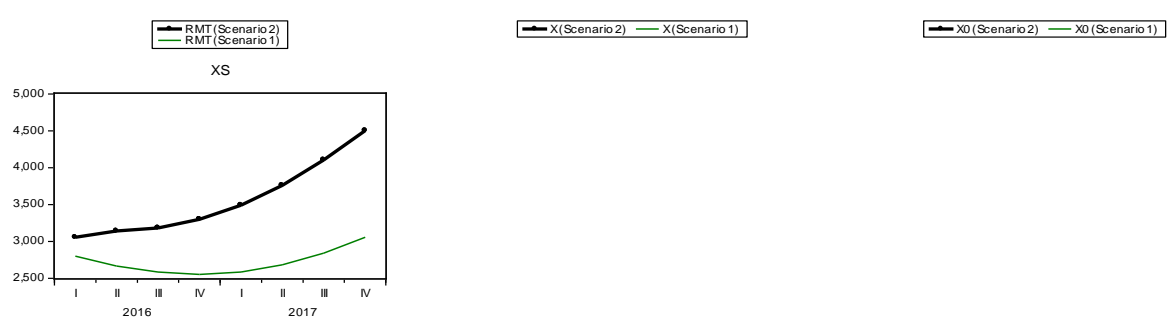

-XS(scenario2) - $\mathrm{x}$ (Scenario 1)

Figure 2. Deviations of external sector components responses to a positive oil price shock. Source: Author's computation. The responses is captured by the bold line and the benchmark by the thinner line. Movements away from the benchmark signifies responses to the Shock.

rates, reserves and remittances. A closer look at the simulation results and the percentage deviations show with a decrease in oil prices to $\$ 35$, the following responses of external sector components were elicited;

1) Current account balance continuously decreases during the forecast period by $5 \%$ and above $6 \%$ in $2016 \mathrm{Q} 1$ and $2017 \mathrm{Q} 4$ respectively.

2) Capital financial flows increase by $0.09 \%$ to $4.48 \%$ in $2016 \mathrm{Q} 1$ and $2017 \mathrm{Q} 4$ respectively.

3) Foreign debt flow increase by $0.27 \%$ to $4.93 \%$ in $2016 \mathrm{Q} 1$ and $2017 \mathrm{Q} 4$ respectively.

4) Foreign direct investment decrease by $0.002 \%$ to $0.089 \%$ in $2016 \mathrm{Q} 1$ and 2017Q4 respectively.

5) Foreign portfolio investments increase by $0.43 \%$ to $2.22 \%$ in $2016 \mathrm{Q} 1$ and 2017Q4 respectively.

6) Imports increase by $0.34 \%$ to $8.84 \%$ in $2016 \mathrm{Q} 1$ and $2017 \mathrm{Q} 4$ respectively.

7) Nominal exchange rates depreciate from $\$ 1: \mathrm{N} 227$ to $\$ 1: \mathrm{N} 228.1$ by $2016 \mathrm{Q} 1$ and from $\$ 1$ :N330.4 to $\$ 1$ N338.1 by 2017Q4. 
Table 13. Response of external sector components to a negative oil price shock.

\begin{tabular}{|c|c|c|c|c|c|c|c|c|c|}
\hline \multicolumn{6}{|c|}{2016} & \multicolumn{4}{|c|}{2017} \\
\hline & Q1 & Q2 & Q3 & Q4 & & Q1 & Q2 & Q3 & Q4 \\
\hline \multicolumn{10}{|c|}{ CA } \\
\hline Scenario 3 ( billion) & -3923.70 & -3144.80 & -2126.90 & -1072.60 & Scenario 3 ( billion) & -109.4 & 671.5 & 1209.70 & 1476.00 \\
\hline Scenario 1 ( billion) & -3727.90 & -2641.70 & -1297.40 & 123.8 & Scenario 1 ( billion) & 1485.20 & 2686.40 & 3659.10 & 4369.80 \\
\hline Deviation ( billion) & -195.9 & -503.1 & -829.5 & -1196.40 & Deviation ( billion) & -1594.60 & -2014.90 & -2449.40 & -2893.70 \\
\hline \% Deviation & 5.3 & 19 & 63.9 & -966.6 & $\%$ Deviation & -107.4 & -75 & -66.9 & -66.2 \\
\hline \multicolumn{10}{|c|}{$\mathrm{CF}$} \\
\hline Scenario 3 ( billion) & -2730.20 & -2726.40 & -2493.40 & -2124.20 & Scenario 3 ( billion) & -1696.90 & -1274.80 & -902.4 & -605.9 \\
\hline Scenario 1 ( billion) & -2732.70 & -2735.80 & $-2,507.50$ & -2143.60 & Scenario 1 ( billion) & -1720.40 & -1301.70 & -931.7 & -636.7 \\
\hline Deviation ( billion) & 2.5 & 9.4 & 14.1 & 19.3 & Deviation ( billion) & 23.5 & 26.9 & 29.3 & 30.8 \\
\hline \% Deviation & -0.09 & -0.34 & -0.56 & -0.9 & $\%$ Deviation & -1.37 & -2.07 & -3.14 & -4.84 \\
\hline \multicolumn{10}{|c|}{ FDF } \\
\hline Scenario 3 ( billion) & 911.3 & 864.8 & 809.8 & 770.6 & Scenario 3 ( billion) & 754.5 & 764.3 & 797.2 & 848.8 \\
\hline Scenario 1 ( billion) & 908.9 & 856.3 & 797.6 & 753.6 & Scenario 1 ( billion) & 732.8 & 737.1 & 764 & 808.9 \\
\hline Deviation ( billion) & 2.5 & 8.5 & 12.2 & 17 & Deviation ( billion) & 21.7 & 27.2 & 33.3 & 39.9 \\
\hline \% Deviation & 0.27 & 1 & 1.53 & 2.25 & \% Deviation & 2.97 & 3.69 & 4.35 & 4.93 \\
\hline \multicolumn{10}{|c|}{ FDI } \\
\hline Scenario 3 ( billion) & 299.1 & 323.3 & 350.3 & 374.1 & Scenario 3 ( billion) & 398.4 & 422.6 & 447.2 & 472 \\
\hline Scenario 1 ( billion) & 299.1 & 323.4 & 350.4 & 374.3 & Scenario 1 ( billion) & 398.6 & 422.9 & 447.6 & 472.4 \\
\hline Deviation ( billion) & -0.01 & -0.03 & -0.06 & -0.11 & Deviation ( billion) & -0.18 & -0.25 & -0.34 & -0.42 \\
\hline \% Deviation & -0.002 & -0.008 & -0.018 & -0.031 & $\%$ Deviation & -0.045 & -0.06 & -0.075 & -0.089 \\
\hline \multicolumn{10}{|c|}{ FPI } \\
\hline Scenario 3 ( billion) & 592.2 & 802.9 & 993.2 & 1155.20 & Scenario 3 ( billion) & 1281.00 & 1368.70 & 1419.90 & 1439.00 \\
\hline Scenario 1 ( billion) & 589.7 & 793.4 & 979 & 1135.80 & Scenario 1 ( billion) & 1257.30 & 1341.50 & 1390.20 & 1407.70 \\
\hline Deviation ( billion) & 2.5 & 9.4 & 14.2 & 19.5 & Deviation ( billion) & 23.7 & 27.1 & 29.6 & 31.3 \\
\hline \% Deviation & 0.43 & 1.19 & 1.45 & 1.71 & \% Deviation & 1.88 & 2.02 & 2.13 & 2.22 \\
\hline \multicolumn{10}{|c|}{ M } \\
\hline Scenario 3 ( billion) & $10,398.50$ & $10,399.20$ & $10,482.70$ & $10,673.20$ & Scenario 3 ( billion) & $10,980.50$ & $11,401.60$ & $11,929.50$ & $12,555.90$ \\
\hline Scenario 1 ( billion) & $10,363.50$ & $10,306.00$ & $10,305.00$ & $10,386.10$ & Scenario 1 ( billion) & $10,556.80$ & $10,812.00$ & $11,142.20$ & $11,536.10$ \\
\hline Deviation ( billion) & 35 & 93.2 & 177.6 & 287.1 & Deviation ( billion) & 423.7 & 589.5 & 787.3 & $1,019.70$ \\
\hline \% Deviation & 0.34 & 0.9 & 1.72 & 2.76 & $\%$ Deviation & 4.01 & 5.45 & 7.07 & 8.84 \\
\hline \multicolumn{10}{|c|}{ NER } \\
\hline Scenario 3 ( $)$ & 228.1 & 244.4 & 260.3 & 276.2 & Scenario 3 ( & 291.8 & 307.4 & 322.8 & 338.1 \\
\hline Scenario $1(\mathbb{N})$ & 227.5 & 242.5 & 257.4 & 272.1 & Scenario 1 ( $)$ & 286.8 & 301.5 & 316 & 330.4 \\
\hline Deviation & 0.52 & 1.97 & 2.99 & 4.02 & Deviation & 4.97 & 5.91 & 6.83 & 7.73 \\
\hline \% Deviation & 0.23 & 0.81 & 1.16 & 1.48 & $\%$ Deviation & 1.73 & 1.96 & 2.16 & 2.34 \\
\hline
\end{tabular}




\section{Continued}

\begin{tabular}{|c|c|c|c|c|c|c|c|c|c|}
\hline \multicolumn{10}{|c|}{ RER } \\
\hline Scenario 3 ( & 2.6 & 2.7 & 2.7 & 2.7 & Scenario 3 ( $)$ & 2.6 & 2.5 & 2.3 & 2.2 \\
\hline Scenario 1 ( & 2.6 & 2.7 & 2.7 & 2.6 & Scenario 1 ( & 2.5 & 2.4 & 2.3 & 2.1 \\
\hline Deviation & 0.006 & 0.022 & 0.031 & 0.039 & Deviation & 0.044 & 0.048 & 0.049 & 0.049 \\
\hline \% Deviation & 0.23 & 0.81 & 1.16 & 1.48 & \% Deviation & 1.73 & 1.96 & 2.16 & 2.34 \\
\hline \multicolumn{10}{|c|}{ RES } \\
\hline Scenario 3 ( billion) & $7.00 \mathrm{E}+06$ & $7.00 \mathrm{E}+06$ & $8.00 \mathrm{E}+06$ & $9.00 \mathrm{E}+06$ & Scenario 3 ( billion) & $1.00 \mathrm{E}+07$ & $1.00 \mathrm{E}+07$ & $1.00 \mathrm{E}+07$ & $1.00 \mathrm{E}+07$ \\
\hline Scenario 1 ( billion) & $6.45 \mathrm{E}+06$ & $6.90 \mathrm{E}+06$ & $7.39 \mathrm{E}+06$ & $7.82 \mathrm{E}+06$ & Scenario 1 ( billion) & $8.22 \mathrm{E}+06$ & $8.55 \mathrm{E}+06$ & $8.83 \mathrm{E}+06$ & $9.06 \mathrm{E}+06$ \\
\hline Deviation ( billion) & 195,758 & 430,681 & 743,810 & $1.11 \mathrm{E}+06$ & Deviation ( billion) & $1.52 \mathrm{E}+06$ & $1.97 \mathrm{E}+06$ & $2.46 \mathrm{E}+06$ & $2.98 \mathrm{E}+06$ \\
\hline \% Deviation & 3 & 6.2 & 10.1 & 14.1 & \% Deviation & 18.5 & 23.1 & 27.9 & 32.9 \\
\hline \multicolumn{10}{|c|}{ RMT } \\
\hline Scenario 3 ( billion) & 1317 & 482.88 & 202.13 & 89.472 & Scenario 3 ( billion) & 42.085 & 20.969 & 11.002 & 6.05 \\
\hline Scenario 1 (billion) & 1318 & 484.07 & 203.16 & 90.223 & Scenario 1 (billion) & 42.601 & 21.318 & 11.238 & 6.2114 \\
\hline Deviation ( billion) & -0.7 & -1.19 & -1.03 & -0.75 & Deviation ( billion) & -0.52 & -0.35 & -0.24 & -0.16 \\
\hline \% Deviation & -0.05 & -0.25 & -0.51 & -0.83 & $\%$ Deviation & -1.21 & -1.64 & -2.1 & -2.6 \\
\hline \multicolumn{10}{|c|}{$\mathrm{X}$} \\
\hline Scenario 3 (billion) & 7212.28 & 7718.69 & 8648.75 & 9793.58 & Scenario 3 (billion) & $11,041.40$ & $12,289.90$ & $13,465.50$ & $14,521.40$ \\
\hline Scenario 1 (billion) & 7411.08 & 8202.28 & 9401.36 & 10835.70 & Scenario 1 ( billion) & $12,381.30$ & $13,927.00$ & $15,389.00$ & $16,713.90$ \\
\hline Deviation ( billion) & -198.8 & -483.6 & -752.6 & -1042.10 & Deviation ( billion) & -1339.90 & -1637.10 & -1923.50 & -2192.50 \\
\hline \% Deviation & -2.7 & -5.9 & -8 & -9.6 & $\%$ Deviation & -10.8 & -11.8 & -12.5 & -13.1 \\
\hline \multicolumn{10}{|c|}{ X0 } \\
\hline Scenario 3 (billion) & 6669.28 & 7153.95 & 8039.65 & 9126.63 & Scenario 3 ( billion) & $10,308.70$ & $11,488.70$ & $12,596.90$ & $13,589.60$ \\
\hline Scenario 1 (billion) & 6868.07 & 7637.47 & 8792.11 & $10,168.40$ & Scenario 1 ( billion) & $11,648.10$ & $13,125.10$ & $14,519.50$ & $15,780.90$ \\
\hline Deviation ( billion) & -198.8 & -483.5 & -752.5 & -1041.80 & Deviation ( billion) & -1339.40 & -1636.40 & -1922.60 & -2191.30 \\
\hline \% Deviation & -2.9 & -6.3 & -8.6 & -10.2 & $\%$ Deviation & -11.5 & -12.5 & -13.2 & -13.9 \\
\hline \multicolumn{10}{|c|}{$\mathrm{XN}$} \\
\hline Scenario 3 ( billion) & 543 & 564.7 & 609.1 & 666.9 & Scenario 3 ( billion) & 732.7 & 801.2 & 868.6 & 931.8 \\
\hline Scenario 1 ( billion) & 543 & 564.8 & 609.2 & 667.2 & Scenario 1 ( billion) & 733.1 & 801.9 & 869.5 & 933 \\
\hline Deviation ( billion) & -0.01 & -0.06 & -0.15 & -0.29 & Deviation ( billion) & -0.47 & -0.69 & -0.92 & -1.15 \\
\hline \% Deviation & 0 & -0.01 & -0.03 & -0.04 & $\%$ Deviation & -0.06 & -0.09 & -0.11 & -0.12 \\
\hline \multicolumn{10}{|c|}{ XS } \\
\hline Scenario 3 ( billion) & 2758.90 & 2590.20 & 2482.40 & 2418.80 & Scenario 3 ( billion) & 2414.80 & 2468.50 & 2577.60 & 2736.00 \\
\hline Scenario 1 ( billion) & 2796.90 & 2663.90 & 2583.10 & 2551.70 & Scenario 1 ( billion) & 2583.80 & 2680.30 & 2839.10 & 3054.40 \\
\hline Deviation ( billion) & -37.9 & -73.7 & -100.7 & -132.8 & Deviation ( billion) & -169.1 & -211.8 & -261.5 & -318.4 \\
\hline \% Deviation & -1.4 & -2.8 & -3.9 & -5.2 & \% Deviation & -6.5 & -7.9 & -9.2 & -10.4 \\
\hline
\end{tabular}

Source: Author's computation. Scenario 3 represents responses of external sector components to an oil price decrease, while Scenario 1 represents the benchmark forecast. Underneath each variable's response is the deviation and percentage deviation of the responses to an oil price increase from the benchmark forecast. 
8) Real exchange rates also depreciate by $0.23 \%$ to $2.34 \%$ in $2016 \mathrm{Q} 1$ and 2017Q4 respectively.

9) Reserves increase by $3 \%$ to $32.9 \%$ in $2016 \mathrm{Q} 1$ and $2017 \mathrm{Q} 4$ respectively.

10) Remittances decrease by $0.05 \%$ to $2.6 \%$ in $2016 \mathrm{Q} 1$ and $2017 \mathrm{Q} 4$ respectively.

11) Total exports decrease by $2.7 \%$ to $13.1 \%$ in $2016 \mathrm{Q} 1$ and $2017 \mathrm{Q} 4$ respectively. Oil exports also decrease by $2.9 \%$ to $13.9 \%$ in $2016 \mathrm{Q} 1$ and $2017 \mathrm{Q} 4$ respectively, while service exports also decrease by $1.4 \%$ to $10.4 \%$ in $2016 \mathrm{Q} 1$ and 2017Q4 respectively. However, non-oil exports decrease marginally by $0.0 \%$, $0.01 \%$ to $0.12 \%$ in $2016 \mathrm{Q} 1$ and $2017 \mathrm{Q} 4$ respectively.

With the decrease in oil prices-as captured by the negative oil price shock, Nigeria does not gains more in foreign exchange earnings which ultimately significantly decreases her reserves and inflow of remittances. With the decrease in reserves, Nigeria will be able to cover less of her imports putting more pressure on the Naira and therefore the currency depreciates in value. The simulation results show an increase in nominal exchange rates, implying that negative oil price shocks will lead to the depreciation of the Naira (see Figure 3).

\section{Findings and Discussions}

The simulation results from this study point to important policy implications for the Nigerian external sector. First, world oil price shocks as captured by the negative and positive shocks to oil prices significantly affects the variables in the external sector. Increases in world oil price lead to increases in capital financial flows, a reduction in foreign debt flows, while oil price reductions significantly lead to increases in imports, depreciation in nominal exchange rates, increases in reserves, reductions in remittances, and increases in capital financial flows. This reflects the over dependence of the Nigerian economy on crude oil, and the justifiable need to diversify the Nigerian economy away from the oil sector.

Also, positive oil price shocks were shown to bring about decreasing responses in capital financial flows, foreign debt flow, foreign portfolio investments, imports, nominal exchange rates, real exchange rates and reserves. However, positive oil price shocks caused substantial increases in total exports, oil exports, non-oil exports, and service exports. The simulations also show that negative oil price brought about decreasing responses in the current account balance, total exports, oil exports, and service exports. However, negative oil price shocks brought about increases in capital financial flows, foreign debt flow, foreign portfolio investments, imports, nominal exchange rates, real exchange rates, reserves and remittances.

Increases in oil prices decrease Nigeria's reserves while increasing the flow of remittances. A negative oil price shock is supposed to have a direct opposite response from the external sector components as compared to the response to a positive oil price shock. With decreases in oil prices, Nigeria loses foreign exchange earnings, which significantly reduces her reserves and remittances 


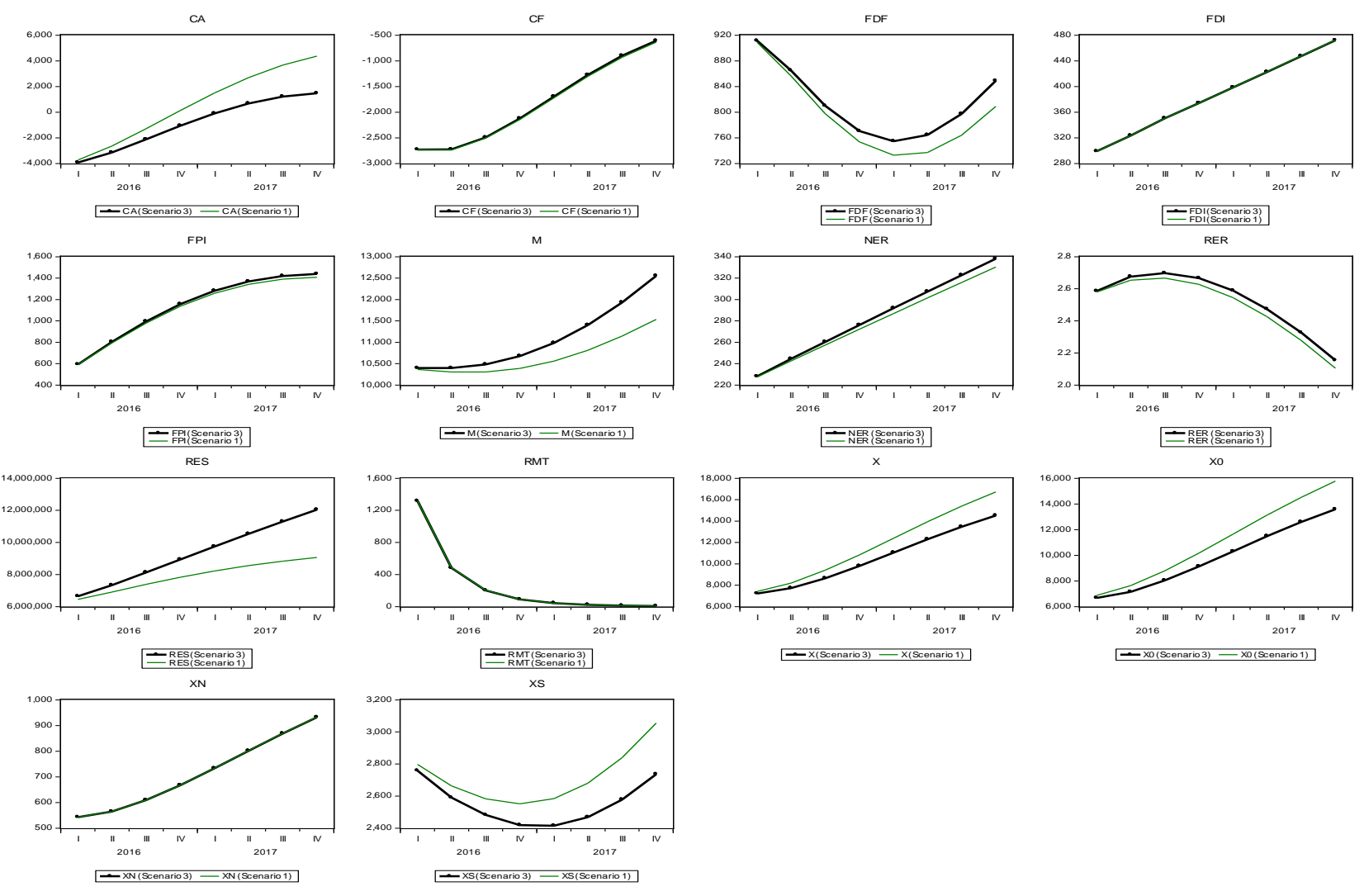

Figure 3. Responses of external sector components to a negative price shock. Source: Author's computation. The responses is captured by the bold line and the benchmark by the thinner line. Movements away from the benchmark signifies responses to the Shock.

inflows. Since Nigeria can now cover less of her imports, we expect imports to reduce and with the loss in foreign exchange we expect the Naira to depreciate in value. The simulated results show that the Naira actually depreciates in value as the nominal exchange rate increases, but imports did not reduce as expected.

Due to the nature of the methodology used-simulations, based on assumptions-making inferential statements on the findings of this study is not sacrosanct. From the stated objectives of this study and the dearth in literature on studies that specifically focus on simulating external sector component's responses to exogenous shocks, making comparative assertions on external sector responses may be challenging. However, the simulated responses are discussed based on a priori expected responses that are hinged on economic intuition and economic theory. Likewise, the findings in [1] are used to check how far off the simulated responses are from the benchmarks. Although in [1], the shock assumptions made, scope of external sector responses, and methodology used are different from those in this study.

The output of the simulation showed that a positive oil price shock brought about significant decreases in capital financial flows, foreign debt flow, foreign portfolio investments, imports, nominal exchange rates, real exchange rates and reserves. However, positive oil price shocks caused substantial increases in total 
exports, oil exports, non-oil exports, and service exports. It must be stated clearly that the responses of non-oil exports and remittances are very small relative to other responses from other external sector components.

With the increase in oil prices-as captured by the positive oil price shock, Nigeria gains more in foreign exchange earnings which ultimately significantly increases her reserves and inflow of remittances. With the increases in reserves, Nigeria will be able to cover more of her imports putting less pressure on the Naira and therefore the currency appreciates in value. The simulation results showed a reduction in nominal exchange rates showing that positive oil price shocks will lead to the appreciation of the Naira but imports did not increase as expected. These findings are in line with those of [22] [26] who all concluded that increases in oil prices, appreciates the exchange rate buy putting less pressures on the Naira as well as improves Nigeria's import cover and reserves. In [1], the simulated results are in conformity with the findings of this study, although the degree to which the Naira appreciates due to the increase in oil prices differ. This difference can be attributed to different assumptions in the changes in oil prices.

As expected, there was a significant increase in reserves and remittances, which seemed to be a permanent change from the benchmark. This increase in reserves and remittances as argued by [18] is possibly only when government's fiscal policy response to the increase in oil prices is considered, citing the possibility of mismanaging windfall revenues from such increase in oil prices. Similarly, total exports, service exports and oil exports behaved similarly with respect to their responses. Relative to total exports, service exports and oil exports, non-oil exports responded with just a marginal increase. This marginal increase in exports point to the import dependent nature of the Nigerian economy as well as the exchange rate depreciation advantage with respect to the inflow of remittance as asserted in [1].

For negative oil price shock, the output of the simulation showed that a negative oil price shock brought about significant decreases in current account balance, total exports, oil exports, and service exports. However, negative oil price shocks also brought about increases in capital financial flows, foreign debt flow, foreign portfolio investments, imports, nominal exchange rates, real exchange rates, reserves and remittances. The simulated results clearly show some form of symmetry in responses to increases and decreases in oil prices. Therefore, it is intuitive to assume that, explanations on the nature of elicited responses for negative oil price shocks would be the direct opposite of those of a positive oil price shock. This conclusion is hinged on the findings of [42] who found no asymmetry with respect to positive and negative oil price changes on Nigeria's real exchange rates.

With the decrease in oil prices-as captured by the negative oil price shock, Nigeria does not gain more in foreign exchange earnings which ultimately significantly decreases her reserves and inflow of remittances. With the decrease in reserves, Nigeria will be able to cover less of her imports putting more pressure 
on the Naira and therefore the currency depreciates in value. The simulation results show an increase in nominal exchange rates, implying that negative oil price shocks will lead to the depreciation of the Naira. These postulates follow those as reported in the findings of [1].

There is a need for government to proactively diversify the economy in order to restructure the components of exports. The unexpected response of imports to both positive and negative shocks to oil prices reflects the import dependence of the Nigerian economy. The composition and nature of Nigerian imports are mainly influenced by domestic factors not external factors. This is a reflection of Nigeria's reliance on oil sector and a need for diversification. Also, there is a need for further research to incorporate domestic factors that determine Nigeria's demand for imports in order to determine the inter relationships between external shocks, imports and domestic macroeconomic variables. The simulation results show that nominal exchange rates policy in response to shocks to oil prices can be used to encourage inflow of remittances and building up Nigeria's reserves.

\section{Conclusions}

The reliance of the Nigerian economy on the proceeds from oil exploration has redirected resources and policy reference from other sectors to principally, the oil sector. This has made the oil sector the main source of foreign exchange, and also an important component of the Nigerian economy as it has both indirect and direct links to Nigeria's reserves, export composition, the capacity to cover her imports, and exchange rates. Despite most studies focusing on the impact of oil price shock, there is detailed evidence in the literature that oil production shocks and output shocks of trade partners do matter in determining both external sector objectives and real domestic macroeconomic objectives.

In trying to elicit responses of external sector components to oil price shocks, this study employed a Structural Macroeconomic Model (SMM) which consisted of ten behavioural equations-which described the relationship between endogenous variables and exogenous variables in the SMM-and four identities which we expect will hold true in reality. Using the Gauss-Seidel technique, we simulated an eight period ahead forecast response of all the endogenous variables in the SMM and compared the responses to a baseline response. The baseline response was simulated under the assumption that all the variables will continue on their trend path without any significant change. The simulated responses for this study found overwhelming evidence that oil price shocks do have substantial effects on Nigeria's external sector components.

\section{Conflicts of Interest}

The author declares no conflicts of interest regarding the publication of this paper.

\section{References}

[1] Central Bank of Nigeria (2013) Modelling the External Sector of the Nigerian 
Economy. Research Department, Abuja.

[2] Akinleye, S.O. and Ekpo, .S. (2013) Oil Price Shocks and Macroeconomic Performance in Nigeria. Economiamexicana, 2, 565-624.

[3] Baumeister, C., Peersman, G. and Robays, I.V. (2010) The Economic Consequences of Oil Shocks: Differences across Countries and Time. In: Fry, R., Jones, C. and Kent, C., Eds., Inflation in an Era of Relative Price Shocks, Sydney, 91-137.

[4] Aloui, R., Gupta, R. and Miller, S.M. (2015) Uncertainty and Crude Oil Returns. Energy Economics, 55.https://doi.org/10.2139/ssrn.2623745

[5] Miero, S. and Ramos, P. (2010) Dutch disease in Macau. Diagnosis and Treatment. http://www.eefs.eu/CONF/Athens/593.pdf

[6] Berument, M.H., Ceylan, N.B. and Dogan, N. (2010) The Impact of Oil Price Shocks on the Economic Growth of Selected MENA Countries. The Energy Journal, 31, 149-176. https://doi.org/10.5547/ISSN0195-6574-EJ-Vol31-No1-7

[7] Natal, J. (2009) Monetary Policy Response to Oil Price Shocks. Federal Reserve Bank of San Francisco, Working Paper Series. https://doi.org/10.24148/wp2009-16

[8] Tazhibayeva, K., Husain, A. and Ter-Martirosyan, A. (2008) Fiscal Policy and Economic Cycles in Oil-Exporting Countries. IMF Working Paper WP/08/253. https://doi.org/10.5089/9781451871111.001

[9] Njiforti, P. (2010) Impact of the 2007/2008 Global Financial Crisis on the Stock Market in Nigeria. CBN Journal of Applied Statistics, 6, 49-68

[10] Park, J. and Ratti, R.A. (2008) Oil Price Shocks and Stock Markets in the U.S. and 13 European Countries. Energy Economics, 30, 2587-2608.

https://doi.org/10.1016/j.eneco.2008.04.003

[11] Hamilton, J. (2009) Understanding Crude Oil Prices. Energy Journal, 30, 179-206. https://doi.org/10.5547/ISSN0195-6574-EJ-Vol30-No2-9

[12] Kilian, L. (2008) Exogenous Oil Supply Shocks: How Big Are They and How Much Do They Matter for The US Economy. Review of Economics and Statistics, 90, 216-240. https://doi.org/10.1162/rest.90.2.216

[13] Kilian, L. and Park, C. (2009) The Impact of Oil Price Shocks on the U.S. Stock Market. International Economic Review, 50, 1267-1287. https://doi.org/10.1111/j.1468-2354.2009.00568.x

[14] Abeng, M.O. and Alehile, K.S. (2012) Macroeconomic Shocks and Fiscal Deficit Behaviour in Nigeria: A VECM Approach. Central Bank of Nigeria Economic and Financial Review, 50, 2-58.

[15] Adeleye, J.O., Adeteye, O.S. and Adewuyi, M.O. (2015) Impact of International Trade on Economic Growth in Nigeria. International Journal of Financial Research, 6, 163-172. https://doi.org/10.5430/ijfr.v6n3p163

[16] Agbede, M.O. (2013) The Growth Implications of Oil Price Shock in Nigeria. Journal of Emerging Trends in Economics and Management Sciences, 4, 343-349.

[17] Akanbi, O.A. and Du Toit, C.B. (2011) Macroeconometric Modelling for the Nigerian Economy: A Growth Poverty Gap Analysis. Economic Modelling, 28, 335-350.

[18] Bardsen, G., Eitrheim, O., Jansen, E.S. and Nymoen, R. (2005) The Econometrics of Macroeconomic Modelling. https://www.researchgate.net/publication/227467797

[19] Bhanumurthy, N.R., Bose, S. and Swayamsiddha, P. (2014) Modelling India's External Sector: Review and Some Empirics. National Institute of Public Finance and Policy, Working Paper, No. 2014-138.

[20] Gurara, D.Z. (2013) A Macroeconometric Model for Rwanda. ADB Working Paper 
Series, No. 177.

[21] Lord, M.J. and ADB (2002) Modelling the Macroeconomy of Bangladesh. MPRA Paper, No. 41171.

[22] Chuku, C.A., Ekpeno, E. and Sam, N. (2010) Oil Price Distortions and Their Shortand Long-Run Impacts on the Nigerian Economy. MPRA Paper No.24434.

[23] Jin, G. (2008) The Impact of Oil Price Shock and Exchange Rate Volatility on Economic Growth: A Comparative Analysis for Russia Japan and China. Research Journal of International Studies, 8, 98-111.

[24] Jiménez-Rodríguez, R. and Sánchez, M. (2005) Oil Price Shocks and Real GDP Growth: Empirical Evidence for Some OECD Countries. Applied Economics, 37, 201-228. https://doi.org/10.1080/0003684042000281561

[25] Juncal, C. and Fernando, P.G. (2000) Do Oil Prices Shocks Matter? Evidence for Some European Countries. Documentos de Economia y Finanzas Internacionales. DEFI 01/02.

[26] Ikla, B.V. (2012) Macroeconomic Impact of Oil Price Shocks on Oil Rich Economies: Evidence from Nigeria Using a Structural VAR Approach. 31 st USAEE/ IAEE North American Conference, Austin, TX, 4-7 November 2012.

[27] Lee, B.R., Lee. K. and Ratti, R.A. (2001) Monetary Policy, Oil Price Shocks and the Japanese Economy. Japan and the World Economy, 13, 321-349. https://doi.org/10.1016/S0922-1425(01)00065-2

[28] Hamilton, J.D. (1996) This Is What Happened to the Oil Price Macroeconomy Relationship. Journal of Monetary Economics, 38, 215-220. https://doi.org/10.1016/S0304-3932(96)01282-2

[29] Farzanegan, M.R. and Markwardt, G. (2009) The Effects of Oil Price Shocks on the Iranian Economy. Energy Economics, 31, 134-151. https://doi.org/10.1016/j.eneco.2008.09.003

[30] Burbidge, J. and Harrison, A. (1984) Testing for the Effects of Oil-Price Rise Using Vector Autoregressions. International Economic Review, 25, 459-484. https://doi.org/10.2307/2526209

[31] Gisser, M. and Goodwin, T.H. (1986) Crude Oil and Macroeconomy: Tests of Some Popular Notions. Journal of Money, Credit and Banking, 18, 95-103. https://doi.org/10.2307/1992323

[32] Cologni, A. and Manera, M. (2008) Oil Prices, Inflation and Interest Rates in a Structural Cointegrated VAR Model for G-7 Countries. Energy Economics, 30, 856-888. https://doi.org/10.1016/j.eneco.2006.11.001

[33] Abhyankar, A., Xu, B. and Wang, J. (2013) Oil Price Shocks and the Stock Market: Evidence from Japan. Energy Journal, 34, 199-222. https://doi.org/10.5547/01956574.34.2.7

[34] Brown, S.P.A. and Yucel, M.K. (2002) Energy Prices and Aggregate Economic Activity: An Interpretative Survey. Quarterly Review of Economics, 51, 679-705.

[35] Cunado, J. and Gracia, F. (2003) Do Oil Price Shocks Matter? Evidence for Some European Countries. Energy Economics, 25, 137-154. https://doi.org/10.1016/S0140-9883(02)00099-3

[36] Lardic, S. and Mignon, R. (2006) The Impact of Oil Prices on GDP in European Countries: An Empirical Investigation Based on Asymmetric Cointegration. Energy Policy, 34, 3910-3915. https://doi.org/10.1016/j.enpol.2005.09.019

[37] Huang, B.N., Hwang, M.J. and Peng, H.P. (2005) The Asymmetry of the Impact of 
Oil Price Shocks on Economic Activities: An Application of the Multivariate Threshold Model. Energy Economics, 27, 455-476.

https://doi.org/10.1016/j.eneco.2005.03.001

[38] Herrera, A.M., Lagalo, L.G. and Wada, T. (2011) Oil Price Shocks and Industrial Production: Is the Relationship Linear? Macroeconomic Dynamics, 15, 472-497. https://doi.org/10.1017/S1365100511000290

[39] Kilian, L. and Vigfusson, R.J. (2011) Are the Responses of the US Economy Asymmetric in Energy Price Increases and Decreases? Quantitative Economics, 2, 419-453. https://doi.org/10.3982/QE99

[40] Schmidt, T. and Zimmermann, T. (2007) Why Are the Effects of Recent Oil Price Shocks So Small? Working Paper, RWI, Essen. https://doi.org/10.2139/ssrn.1088057

[41] Blanchard, O.J. and Gali, J. (2007) The Macroeconomic Effects of Oil Price Shocks: Why Are the 2000s So Different From the 1970s? MIT Department of Economics, Working Paper 13368. https://doi.org/10.3386/w13368

[42] Ayadi, O.F. (2005) Oil Price Fluctuations and the Nigerian Economy. OPEC Review, 29, 199-217. https://doi.org/10.1111/j.0277-0180.2005.00151.x

[43] Fair, R.C. (1984) Specification, Estimation and Analysis of Macro Econometric Models. Harvard University Press, Cambridge, MA. 